\title{
Aforar, arrumar e alinhar: a atuação da Câmara Municipal de Belém na configuração urbano- fundiária da cidade durante o século XIX'
}

Enfhyteusis, land demarcation and land alignment: the performance of Belém's City Council in urban configuration and land management during the 19th century

\author{
PAULA VANESSA LUZ DE ABREU² \\ Universidade Federal do Pará / Belém, PA, Brasil \\ JOSÉ JÚLIO FERREIRA LIMA ${ }^{3}$ \\ Universidade Federal do Pará / Belém, PA, Brasil
}

\author{
LULY RODRIGUES DA CUNHA FISCHER ${ }^{4}$ \\ Universidade Federal do Pará / Belém, PA, Brasil
}

RESUMO: $\bigcirc$ artigo examina a transformação morfológica da cidade de Belém do Pará influenciada pelo novo regime fundiário inaugurado com a Lei de Terras de 1850 e pelo crescimento do planejamento urbano estatal. Investiga-se a atuação da Câmara Municipal no ordenamento urbano-fundiário da cidade e na implementação de um Plano de Expansão para Belém no século XIX. Para compreender as ações espaciais empreendidas pela Câmara, partese do estudo de três instrumentos: o aforamento, que constituía a principal forma de transmissão de terra utilizada pela Câmara Municipal; o alinhamento, relacionado com a definição de vias e limites público-privado; e a arrumação, referente à demarcação das terras aforadas. Foram investigados os documentos fundiários originais que registram as ações de aforamento, alinhamento e arrumação realizadas pela Câmara ao longo da Estrada de Bragança, principal eixo de expansão da cidade nos oitocentos. A partir da espacialização gráfica das informações contidas nos documentos fundiários e da pesquisa em periódicos locais, foi possível verificar que a Câmara atuou pioneiramente como agente loteador, com um projeto sistemático de partilha da terra. Esta discussão contribui para a compreensão do papel estruturador do poder local na

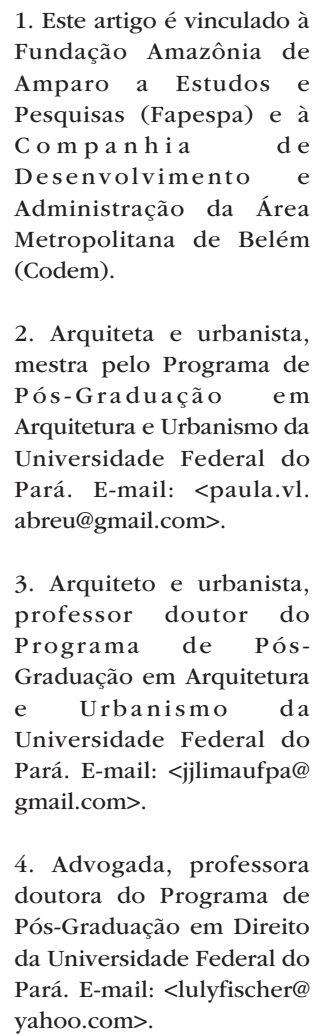

2. Arquiteta e urbanista, mestra pelo Programa de Pós-Graduação em Arquitetura e Urbanismo da Universidade Federal do Pará. E-mail: <paula.vl. abreu@gmail.com>.

\begin{abstract}
3. Arquiteto e urbanista, professor doutor do Programa de PósGraduação em Arquitetura e Urbanismo da Universidade Federal do Pará. E-mail: <jjlimaufpa@ gmail.com>.
\end{abstract}

4. Advogada, professora doutora do Programa de Pós-Graduação em Direito da Universidade Federal do Pará. E-mail: <lulyfischer@ yahoo.com>. 
definição e alteração da morfologia urbana e para um novo entendimento do Plano de Expansão de Belém, classificando-o não apenas como um projeto estatal de ordenamento e embelezamento urbano, mas como produto da transição político-fundiária que marca o século XIX.

PALAVRAS-CHAVE: Morfologia urbana. Aforamento. Alinhamento. Loteamento. Câmara Municipal. Plano de Expansão de Belém.

ABSTRACT: The paper examines the morphological transformation of the city of Belém, influenced by the new land regime inaugurated by the Land Law of 1850 and by the growth of state urban planning. We investigate the actions of the City Council in the urban land tenure and the implementation of an Expansion Plan for Belém in the 19th century. In order to understand the spatial actions undertaken by the City Council, we started from the study of three instruments: emphyteusis, the main form of land transfer used by the City Council; alignment, related to the public-private boundaries and streets definitions; and land demarcation. We investigated the original land documents that record the emphyteusis, alignment and land demarcation carried out by the City Council along the Bragança Road, the main axis of city expansion in the 19th century. From the graphic spatialization of the information contained in these documents and the research in local newspapers, it was possible to verify that the City Council acted as a pioneer state agent, through a systematized land subdivision project. The discussion contributes to the comprehension of the structuring role of the local power in the definition and change of urban morphology and to a new understanding of the Belém Expansion Plan, classifying it as not only a urban beautification project, but as a product of the political-land tenure transition that marks the nineteenth century.

KEYWORDS: Urban morphology. Emphyteusis. Alignment. Land subdivision. City Council. Belém Expansion Plan. 
No século XIX, Belém do Pará passou por significativas transformações em meio ao processo de modernização urbana. A cidade foi impactada tanto por medidas de ordenamento espacial como por ações de definição fundiária, articuladas pela gestão da Câmara Municipal. Ao conjugar funções jurídicas e administrativas, a Câmara fazia valer disposições oriundas da ordem fundiária proveniente da condição colonial brasileira. Detinha as funções de legislar e administrar os concelhos, ${ }^{5}$ que eram as menores unidades político-territoriais da administração portuguesa e desfrutavam de autonomia judiciária e administrativa. ${ }^{6}$ Quando fundadas, as Câmaras recebiam, por meio de doação, uma porção de terras para constituir seu patrimônio, que deveria ser utilizado para ocupação da vila ou cidade. A Câmara Municipal exercia, portanto, o controle fundiário sobre essas terras, podendo concedê-las a particulares por meio de aforamento e, assim, obter um rendimento anual, conhecido como foro.

sistema de aforamento caracterizava-se pela existência de dois senhorios sobre a terra: o foreiro ou enfiteuta, que recebia o domínio útil (direito de utilizar o bem); e o senhorio, que ao aforar sua terra passava a deter apenas o domínio direto. $\bigcirc$ domínio direto conferia ao senhorio o direito de receber o foro, quantia anual paga pelo foreiro para utilização da terra, e o laudêmio, porcentagem sobre o valor da transação do imóvel sempre que o domínio útil fosse alienado.?

Nesse sentido, o poder local, que até a implantação da República foi representado pela Câmara Municipal, tinha a prerrogativa de dispor de seu patrimônio, enquanto detentor das terras, ${ }^{8}$ e de implementar ações de ordenamento urbano em toda sua área de jurisdição. ${ }^{9}$ A partir do século XIX, a atuação do poder local sobre o espaço urbano se tornou mais contundente e sistemática, por meio de ações de melhoria urbana e planos de remodelação da forma da cidade, implementados em diversas cidades do Brasil e do mundo. ${ }^{10}$

Ainda naquele século, transições políticas, legislativas e ideológicas impactaram a questão fundiária no Brasil e, consequentemente, a atuação do poder local na estruturação fundiária e morfológica da cidade. A Lei de Terras, de 1850, reordenou a forma de apropriação das terras públicas no Brasil, afastando-a do modelo tradicional, calcado na concessão e no aforamento para uso e exploração da terra, e inserindo-a em um modelo econômico no qual a terra se configura como mercadoria. Apesar de a lei não atuar sobre áreas urbanas e patrimônios municipais, as mudanças no contexto político, econômico e fundiário reverberaram sobre os processos fundiários que ocorriam na cidade. ${ }^{11}$
5. O Dicionário Priberam da Lingua Portuguesa (2018) conceitua a palavra "concelho" como "Subdivisão do distrito administrativo com pos ta de uma ou mais freguesias" e traz como sinônimos os termos "câmara" e "município”. A palavra concelho ainda é utilizada em Portugal para designar o que no Brasil viria a se chamar de município. Como as estruturas administrativas aqui estabelecidas reproduziram o modelo português, o termo concelho está presente em grande parte dos documentos históricos aqui estudados e, por isso, os termos município e concelho serão utilizados como sinônimo neste artigo. Utilizaremos ainda o termo "Município" (com inicial maiúscula) e a expressão "poder local" para representar o governo executivo e fazer referência às instituições responsáveis pela administração dos concelhos/municípios no Brasil, que incluem: a Câmara Municipal (desde o início da Colonização até o fim do Período Imperial); o Conselho de Intendência (1889-1905); a Intendência Municipal (1905-1930); e, finalmente, a Prefeitura (de 1930 até hoje). Cabe ressaltar que, embora nos primeiros séculos da ocupação brasileira o termo utilizado para designar o ente administrativo local fosse concelho e não município, a expressão "Câmara Municipal” já existia e aparece, inclusive, no requerimento para demarcação da légua patrimonial de Belém em 1702 (Cruz, 1973, p. 180).

6. Cf. Fonseca (2011).

7. Cf. Freitas (2003).

8. Cf. Abreu (1997); Glezer (2007a); Marx (1991).

9. Cf. Brasil (1828); Glezer (2007a); Miranda (2000).

10. Cf. Benevolo (2009); Duarte (1997b); Segawa (2010). 
11. Cf. Glezer (2007a); Nascimento (2013); Simoni (2009).

12. Cf. Fonseca (2011, 2012).

13. Cf. Duarte (1997a, 1997b); Lobato et al. (2005).
Nesse cenário, a atuação do poder local passa a ser influenciada tanto por uma nova forma de conceber a propriedade da terra como pela necessidade de reordenar o espaço urbano e remodelar a cidade. Essa última questão tem sido objeto de pesquisa em diversas cidades brasileiras, o que tem contribuído, em parte, para entender importantes transformações trazidas pelo século XIX. Por outro lado, a questão fundiária e sua relação com a estruturação das cidades é campo menos explorado, e os principais estudos sobre o assunto se direcionam para a formação de cidades nos séculos XVII e XVIII. ${ }^{12}$ Assim, a questão fundiária no cenário de transformação econômica, política e ideológica dos oitocentos, com a qual está entrelaçada a atuação do Estado no ordenamento urbano, é um campo aberto para pesquisas interdisciplinares abrangendo história, geografia, arquitetura, urbanismo, direito e ciências sociais.

Ao focar a administração urbanística e fundiária de Belém durante o século XIX, examina-se a atuação do poder local como ordenador da ocupação de terras municipais, responsável pela implantação de um "plano de expansão da cidade" viabilizado por aforamento e alinhamento de terrenos enquanto componentes de modificações morfológicas. A pesquisa baseou-se na análise de medidas vinculadas à concessão de terras do patrimônio municipal e à ocupação ao longo da Estrada de Bragança, eixo de expansão urbana. Para isso, o artigo contextualiza a origem do traçado de Belém, relacionando-o com a expansão da malha viária planejada pela Câmara Municipal.

Esta análise contribui para um novo entendimento da expansão da cidade no século XIX, que até então foi atribuída ao planejamento do engenheiro municipal Manoel Odorico Nina Ribeiro e à gestão do Intendente Antônio Lemos, no final do século. A historiografia sugere que o arruamento foi produto do Plano de Expansão citado, ${ }^{13}$ porém, não se encontram referências à origem do desenho dos lotes. Tal lacuna na historiografia justifica este estudo de caráter exploratório, que busca articular a morfologia da cidade com os aspectos jurídico-administrativos que regem a administração municipal e a propriedade fundiária. A pesquisa histórica e o conhecimento das datas de demarcação dos primeiros terrenos ao longo da Estrada de Bragança permitem compreender o plano de expansão municipal não apenas como uma iniciativa de embelezamento da cidade, típica das ações municipais na virada do século, mas dentro de um processo fundiário oriundo das transformações na mentalidade proprietária, que inclui o parcelamento do solo, loteamento e criação de reserva de terras.

A atuação do poder local sobre o patrimônio municipal no século XIX testemunha, portanto, de um período histórico peculiar marcado pelo entendimento da terra enquanto mercadoria, pelo planejamento urbano como instrumento de ordenamento da cidade e pela atuação direta e articulada da Câmara enquanto Estado e agente fornecedor de terras. 
Entender a atuação do poder local na estruturação fundiária e no ordenamento urbano de Belém passa pela compreensão do funcionamento de instrumentos jurídicos e urbanísticos que impactavam tanto o status da terra quanto a forma de lotes e vias. Assim, além do aforamento, que foi o instrumento mais utilizado para alienação das terras pertencentes à Câmara de Belém, dois outros procedimentos merecem atenção especial: o alinhamento, que consistia na definição da fronteira entre o terreno e a via, distinguindo limites público-privados; e a arrumação, que se caracterizava pela demarcação in loco do terreno aforado, garantindo a espacialização das medidas atestadas nos documentos de aforamento e estabelecendo limites com terrenos confinantes.

Os três instrumentos são subsídios para o estudo, tanto em seus aspectos morfológicos quanto jurídico-fundiários, posto que estão intimamente entrelaçados. A discussão conceitual e doutrinária sobre eles, inclusive com o entendimento jurídico mais aprofundado sobre o instituto da enfiteuse, permite compreender as peculiaridades desses processos na cidade de Belém e seus desdobramentos até os dias atuais.

Os documentos jurídicos que atestam ações da Câmara Municipal, denominados "termos de aforamento" e "termos de alinhamento e arrumação", fazem parte atualmente do acervo da Companhia de Desenvolvimento e Administração da Área Metropolitana de Belém (Codem),,$^{14}$ empresa de economia mista com 99\% das ações pertencentes ao Município, constituída em 1970 com o objetivo de "administrar e explorar economicamente os bens de uso especial/15 e os bens dominicais ${ }^{16}$ da Prefeitura de Belém". ${ }^{17}$

A metodologia empregada para investigação morfológica consistiu em: (1) exame e transcrição de documentação histórica, composta por 32 termos de aforamento e 11 termos de alinhamento e arrumação de terrenos localizados na Estrada de Bragança;i' (2) espacialização gráfica das dimensões e localizações indicadas nesses documentos; e (3) contraposição entre esses dados e plantas históricas do local. Cotejou-se, a partir desses procedimentos, a relação entre os processos de aforamento e parcelamento intermediados pelo poder local. Além disso, a pesquisa em periódicos de circulação local serviu de apoio para esclarecer algumas questões referentes à gestão municipal e aos interesses dos membros da Câmara.

As questões tratadas ao longo deste artigo se desenrolam na mesma linha de pesquisa desenvolvida pela escola inglesa de morfologia urbana, ${ }^{19}$ que aborda aspectos morfológicos em seu caráter histórico-geográfico, considerando a importância da parcela de terra na compreensão da gênese e das transformações
14. Com a criação da Codem, na década de 1970 , a integração que havia entre a administração das terras municipais e a gestão urbanística para novos loteamentos e arruamentos foi parcialmente rompida, já que a interferência do órgão nos aspectos urbanísticos possui mais caráter de consultoria e planejamento. O direcionamento na execução de obras públicas e a regulação de uso e ocupação do solo e edificações passaram a ser exercidos por secretarias específicas da administração municipal.

15. Segundo o Código Civil brasileiro (Cf. Brasil, 2003), bens públicos de uso especial são aqueles utilizados para a execução de serviços administrativos, independentemente de sua titularidade, tais como edifícios ou terrenos destinados a uso especial. Incluem hospitais, cemitérios públicos, quartéis, escolas, museus, aeroportos, repartições públicas, etc.

16. Segundo o Código de Contabilidade Pública da União, bens dominicais são classificados como "bens patrimoniais disponíveis", sendo alienáveis. Os bens dominicais "não têm destinação pública definida, razão pela qual podem ser aplicados pelo Poder Público, para obtenção de renda; é o caso das terras devolutas, dos terrenos de marinha, dos imóveis não utilizados pela Administração, dos bens móveis que se tornem inservíveis" (Di Pietro, 2008, p. 632).

17. Cf. Belém (1970).

18. A Estrada de Bragança deveria ligar a capital paraense ao nordeste do estado, estendendo-se por mais de duzentos 
quilômetros. A área estudada neste trabalho compreende apenas $o$ trecho da Primeira Légua Patrimonial de Belém, com aproximadamente três quilômetros entre o fim da Avenida Independência (atual Av. Magalhães Barata) e o Boulevard da Câmara (atuais Av. Dr. Freitas e Av. Perimetral).

19. Cf. Conzen (2001); Moudon (1997).

20. Cf. Guimarães (2006).

21. Cf. Moreira (1966).

22. Cf. Franco (1986).

23. Muniz (1904, p. 94). do tecido urbano. A reconstituição da origem fundiária dos terrenos e o entendimento da atuação da Câmara Municipal por meio do aforamento, do alinhamento e da arrumação, permitiram compreender a atuação do poder local no contexto de transição político-jurídica de meados do século XIX e seus impactos na morfologia da cidade que se desdobram até os dias atuais.

\section{A ESTRUTURA URBANA DE BELÉM}

A cidade de Belém foi fundada e formada como ponto importante para a proteção do território brasileiro, sob disputa entre portugueses e franceses. ${ }^{20} \mathrm{~A}$ forma triangular do sítio escolhido permitia comunicação, de um lado, com o mar através da baía de Guajará, e de outro, com o interior, pelo rio Guamá características físicas que tornavam o sítio adequado tanto para defesa quanto para ocupação do território. ${ }^{21}$

A ocupação da cidade se inicia no entorno do Forte do Presépio e se expande com a abertura das primeiras ruas direcionadas aos conventos carmelitas e franciscanos, fundados em 1626, que funcionaram como polos atrativos da ocupação. ${ }^{22}$ Cerca de uma década após a fundação da cidade e logo depois da chegada das ordens religiosas, a Coroa Portuguesa doa à Câmara Municipal uma sesmaria para formação de seu patrimônio, dentro das medidas políticas adotadas pela Metrópole para a conformação de cidades e suas estruturas administrativas. A doação, realizada por meio do governador e capitão-general do Maranhão, Francisco Coelho de Carvalho, em $1^{\circ}$ de setembro de 1627, abrangia área de uma légua de terras a partir do Forte do Castelo, que ficou conhecida como a Primeira Légua Patrimonial de Belém:

doar d'este dia para todo sempre, por carta de doação e sesmaria, à dita Câmara desta cidade uma légua de terra ao redor d'esta cidade, e todas as datas que dentro da dita légua estiverem dadas o sejam adeante, e para que fique a dita légua de terra livre para o Conselho de todas as suas águas, lenhas, madeiras, serventias e pastos que na dita légua de terra houver [...]. E mando aos officciaes a quem pertencer deêm posse e demarquem a dita légua de terra à Câmara d'esta Cidade ou a quem poder tiver, para que logrem e possuam a dita Câmara e seus sucessores, e para que d'ella e em ella façam o que the bem aprouver. ${ }^{23}$ 
Assim, a Câmara Municipal recebe sua sesmaria quando a ocupação ainda era extremamente limitada e rarefeita. ${ }^{24}$ Embora as ordens religiosas tenham desempenhado importante papel no direcionamento da ocupação de Belém, acredita-se que sua influência na estruturação fundiária da cidade foi pouco relevante, uma vez que já estava estabelecido o domínio da Câmara sobre a área que se estendia por uma légua de terras a partir do Forte. ${ }^{25}$ Logo, estabeleceu-se em Belém uma estrutura fundiária peculiar, onde a Câmara detinha o domínio hegemônico das terras do núcleo de fundação da cidade e de seu entorno, não competindo com a Igreja ou particulares o domínio fundiário, como ocorrido em outras cidades. ${ }^{26}$

A Câmara de Belém tomou posse da sesmaria recebida no dia 29 de março de 1628. Logo em seguida, os marcos que definiam a légua foram implantados, mas desapareceram com os anos, ${ }^{27}$ exigindo uma nova demarcação, realizada em 1703. Após a doação e demarcação, era necessário que a sesmaria recebida fosse confirmada pelo rei para que se tornasse válida. ${ }^{28}$ Em 30 de abril de 1708, a sesmaria da Câmara Municipal foi confirmada por meio de Carta Régia ${ }^{29}$ e, a partir de então, o Município tornou-se hábil para conceder terras dentro de seu patrimônio.

É importante distinguir o patrimônio do Concelho, que era composto de terras pertencentes à Câmara Municipal, do território que estava sob sua administração. Esse território era conhecido como o termo do Concelho e, em geral, correspondia a uma área consideravelmente maior que a do patrimônio municipal. Isso porque a Câmara Municipal era, por vezes, responsável por administrar não apenas a sede do Concelho, mas também povoações e áreas rurais que não gozavam de autonomia jurídico-administrativa. ${ }^{30}$ Corroborando com essa distinção entre patrimônio e termo, Corrêa ${ }^{31}$ esclarece que o direito do Município sobre seu patrimônio integra o chamado jus dominii (direito de dono), o qual não se confunde com o jus imperii (direito de governar) que exerce enquanto poder público sobre sua área de jurisdição. ${ }^{32}$ Nesse sentido, o patrimônio da Câmara limitava-se à Primeira Légua Patrimonial, mas a área de sua jurisdição (termo) extrapolava esse limite e abarcava diversos povoados e freguesias lou paróquias) do interior do estado.

Não havia regulação a respeito da área máxima do termo de uma vila ou cidade, pois era conveniente que este abrangesse os povoados mais distantes, de modo a submetê-los à administração da Câmara, garantindo seu controle. ${ }^{33}$ Quanto à área mínima dos termos municipais, o regimento passado a Tomé de Sousa (governador-geral entre 1549 e 1553), definia que, no caso das cidades a serem fundadas como sede do governo-geral, os termos deveriam abranger seis léguas para cada parte (considerando-se o pelourinho como centro). ${ }^{34}$
24. Cf. Cruz (1973); Meira Filho (1976); Penteado (1988).

25. Não se aprofunda neste trabalho o papel da Igreja e suas propriedades de terra na estruturação fundiária de Belém, já que a questão dominial na primeira década da ocupação da cidade pouco foi investigada e ainda ne ces s it a esclarecimentos.

26. Cf. Fridman (1999), para o caso do Rio de Janeiro, e Glezer (2007a) para o caso de São Paulo.

27. Cf. Cruz (1973).

28. Cf. Lima (1990).

29. Cf. CODEM (1998); Muniz (1904).

30. Cf. Fonseca (2011).

31. Cf. Corrêa [19--].

32. Cf. Corrêa [19--].

33. Cf. Fonseca (2011).

34. Cf. Fridman (1999); Mota (2012). 
35. Cf. Godoy (2015).

36. Cabe destacar que somente dentro do seu patrimônio a Câmara Municipal poderia aforar terras; nas outras localidades, competia-lhe apenas a administração local, que poderia incluir regulações urbanas e o alinhamento de terrenos e edificações. A atuação da Câmara fora de sua légua patrimonial não constitui objeto deste estudo, de modo que não é possível afirmar se, de fato, a Câmara de Belém realizou tais atos de regulação urbana e alinhamento sobre as paróquias do interior do estado.

37. Cf. Pará (1861).
No caso da Vila de São Paulo, por exemplo, havia dúvidas a respeito da área de seu termo, já que a vila, ao contrário do que era comum, não possuía um foral de criação. Como consequência, chegou a haver sobreposição entre o que a Câmara de São Paulo considerava sua área de jurisdição lem razão do próprio exercício jurídico-administrativo e mesmo tributário sobre as freguesias e povoações vizinhas) e a Vila de São Vicente. Posteriormente, um despacho real garantiu a posse de seis léguas de cada lado à Vila de São Paulo, por ser esta a mais antiga. Contudo, na prática, a jurisdição da Câmara se estendia por uma área ainda maior, chegando a compreender localidades distantes cerca de doze léguas do município. Com o decorrer do tempo, algumas freguesias sob o termo do Município se desenvolveram e adquiriram status de vila, o que significa que passariam a desfrutar de autonomia jurídico-administrativa, saindo da jurisdição da Câmara paulista. Com isso, a área do termo foi diminuindo progressivamente, mantendo-se, entretanto, as seis léguas para cada lado que haviam sido garantidas pelo foral..$^{35}$

Não é possível afirmar que a cidade de Belém possui carta de foral com indicação da área do termo, mas pode-se ter ideia da abrangência da área de jurisdição da Câmara por meio do registro de colégios eleitorais da província do Pará, que identificava doze paróquias vinculadas à cidade de Belém ${ }^{36} \mathrm{em}$ meados do século XIX. ${ }^{37}$ Destas, apenas três (Sé, Santa Anna e Trindade) estavam dentro dos limites da Primeira Légua Patrimonial; as demais paróquias se localizavam no interior da província, incluindo localidades distantes cerca de 130 quilômetros do ponto inicial de demarcação da légua, onde se iniciou a ocupação da cidade. Há de se considerar que, ao longo do tempo, o número de paróquias atreladas à administração da Câmara belenense sofreu diversas variações, decorrentes tanto do surgimento de novas paróquias (que poderiam ser incluídas na área de jurisdição do Município) quanto da elevação de algumas delas à categoria de vila, momento em que adquiriam autonomia político-administrativa e desvinculavam-se da gestão da Câmara de Belém.

Em termos dominiais, não era incomum que as terras recebidas pelas Câmaras Municipais se sobrepusessem aos terrenos pertencentes à lgreja, de modo a gerar conflitos fundiários a respeito da titulação de terras e do direito de recebimento dos foros. Foi o caso, por exemplo, da cidade do Rio de Janeiro, onde a propriedade dos jesuítas los maiores detentores de terra na cidade até sua expulsão, no período pombalino) conflitava com a sesmaria da Câmara. Soma-se a isso o fato de os próprios governadores autorizarem doações de sesmarias em áreas do patrimônio da Câmara, agravando a situação de sobreposição de domínios em terras municipais. A situação foi em parte controlada pela disposição trazida por uma Carta Régia em 1713, que atribuía à Câmara do Rio de Janeiro 
a responsabilidade pela distribuição das terras dentro do termo do Município, ainda que não pertencessem ao patrimônio municipal. Portanto, no caso do Rio de Janeiro, a existência de diversos agentes responsáveis por concessões de terra, como governadores, capitães-mores, a Câmara Municipal e ordens religiosas, em um contexto no qual a demarcação de terras era cara e precária, conduziu à superposição de domínios e à grilagem das terras públicas, gerando diversos conflitos fundiários que exigiam a intervenção da Coroa para serem contornados. ${ }^{38}$

Em Belém, a Câmara Municipal, por meio da sesmaria recebida, tornou-se a principal, senão a única, responsável por conceder terras dentro da Primeira Légua Patrimonial, não havendo tão expressiva participação da lgreja ou de particulares. Assim, conflitos entre a Câmara e as ordens religiosas foram situações isoladas, em que a lgreja não refutava a dominialidade da Câmara, mas julgava ter privilégios para ocupar terrenos municipais. ${ }^{39} \bigcirc$ domínio hegemônico da Câmara sobre grande parte da cidade conferiu-he poder de estruturar o arruamento, o desenho e a ocupação de novos lotes por meio do aforamento de seus terrenos. Contudo, foi somente a partir do século XIX, com o crescimento mais significativo da população e da economia urbana e com a noção de valor de troca da terra, que a Câmara Municipal passou a se valer de sua posição privilegiada como Estado e proprietário fundiário, atuando sistematicamente na partilha de terras por meio de ações de loteamento.

\section{O PLANO DE EXPANSÃO DE BELÉM}

Ao longo do século XIX as mudanças no contexto fundiário, com a instituição da propriedade privada da terra, e no âmbito urbano, com a implementação de normativas e ações voltadas para o ordenamento urbano e controle social, se conjugam e trazem grandes impactos para a morfologia das cidades. As medidas de intervenção urbana são resultado de uma concepção higienista de cidade, calcada na limpeza, na salubridade e no ordenamento. ${ }^{40}$ Para atingir o objetivo da cidade salubre e moderna, fazia-se necessário adequar espaços e residências aos preceitos higienistas, em contraposição à morfologia da cidade tradicional. ${ }^{41}$ Como consequência, foram recorrentes no século XIX e início do século XX as intervenções sobre o traçado da cidade e as ações de ordenamento urbano, como: calçamento, alinhamento e alargamento de vias; limpeza urbana; aterro ou desprezo das áreas alagadas; e normativas sobre construções urbanas, expressas em códigos de posturas municipais. ${ }^{42}$
38. Cf. Fridman (1999).

39. Cf. Meira Filho (1976).

40. Cf. Benevolo (2009).

41. Cf. Segawa (2010).

42. Cf. Sarges (2000). 
43. Cf. Duarte (1997b).

44. Cf. Marx (1991).

45. Cf. Nascimento; Maia (2011).

46. Cf. Benevolo (2009)

47. Cf. Duarte (1997a, 1997b); Lobato et al. (2005).

48. Cf. Muniz (1904).

49. Cf. Duarte (1997a, 1997b).

50. Cf. Duarte (1997b).
Assim, a forma das cidades será impactada tanto pelas medidas de ordenamento espacial oriundas das correntes de pensamento higienistas e "modernizadoras", quanto pela instituição da propriedade privada da terra e pelo surgimento do mercado imobiliário e do loteamento. É nesse momento que a malha urbana ortogonal se propaga em diversas cidades do Brasil e do mundo, pois sua regularidade tanto atende à demanda de modernização da cidade, por meio de um traçado simbólica e funcionalmente diferenciado do traçado mais irregular dos núcleos urbanos tradicionais, ${ }^{43}$ quanto facilita o parcelamento do solo em lotes destinados à comercialização. ${ }^{44}$ Além disso, é importante ressaltar que as intervenções e melhorias urbanas realizadas pelo Estado corroboravam e incrementavam o processo de valorização da terra urbana. ${ }^{45}$

A malha viária ortogonal e regular da área de expansão de Belém no século XIX indica um traçado planificado que remete às transformações urbanísticas implementadas ao redor do mundo na segunda metade dos oitocentos, das quais as principais referências internacionais são os planos para reforma de Paris e Barcelona. ${ }^{46} \mathrm{~A}$ historiografia local tem atribuído o desenho do traçado ao Plano de Expansão de Belém, que teria sido desenvolvido entre 1883 e 1886 pelo engenheiro Nina Ribeiro. ${ }^{47}$

Nesse período, uma nova demarcação da sesmaria da cidade foi solicitada pela vereação, cabendo ao engenheiro da Câmara, Manoel Odorico Nina Ribeiro, executála ${ }^{48}$ Cristovão Duarte defende a ideia de que Nina Ribeiro não apenas atendeu ao requerimento de demarcação da propriedade do Município, mas também realizou um levantamento do núcleo urbano de Belém e elaborou um projeto de expansão da cidade, prevendo a ocupação de toda a Primeira Légua Patrimonial. $O$ desenho de Nina Ribeiro (Figura 1) define quatro setores de malha ortogonal, rotacionados entre si, para que pudessem se encaixar dentro do arco formado pelo limite da Primeira Légua Patrimonial. Cada setor se comunica com o adjacente e com o núcleo de ocupação da cidade: os eixos de penetração do núcleo urbano são prolongados e se transformam em geratrizes para o desenho da área de expansão. ${ }^{49}$

Alguns setores, entretanto, por estarem mais próximos do núcleo urbano central e por se originarem do prolongamento de suas vias, apresentam uma malha viária de escala mais próxima deste. À medida que se vai afastando do núcleo, a escala das quadras e vias aumenta, como no caso do parcelamento ao longo da Estrada de Bragança. Essa área, por ser distante da malha viária existente, teria permitido ao autor do plano um desenho quase sem influências da estrutura do núcleo urbano, com avenidas que possuíam cerca de 44 metros de caixa de via. ${ }^{50}$ 


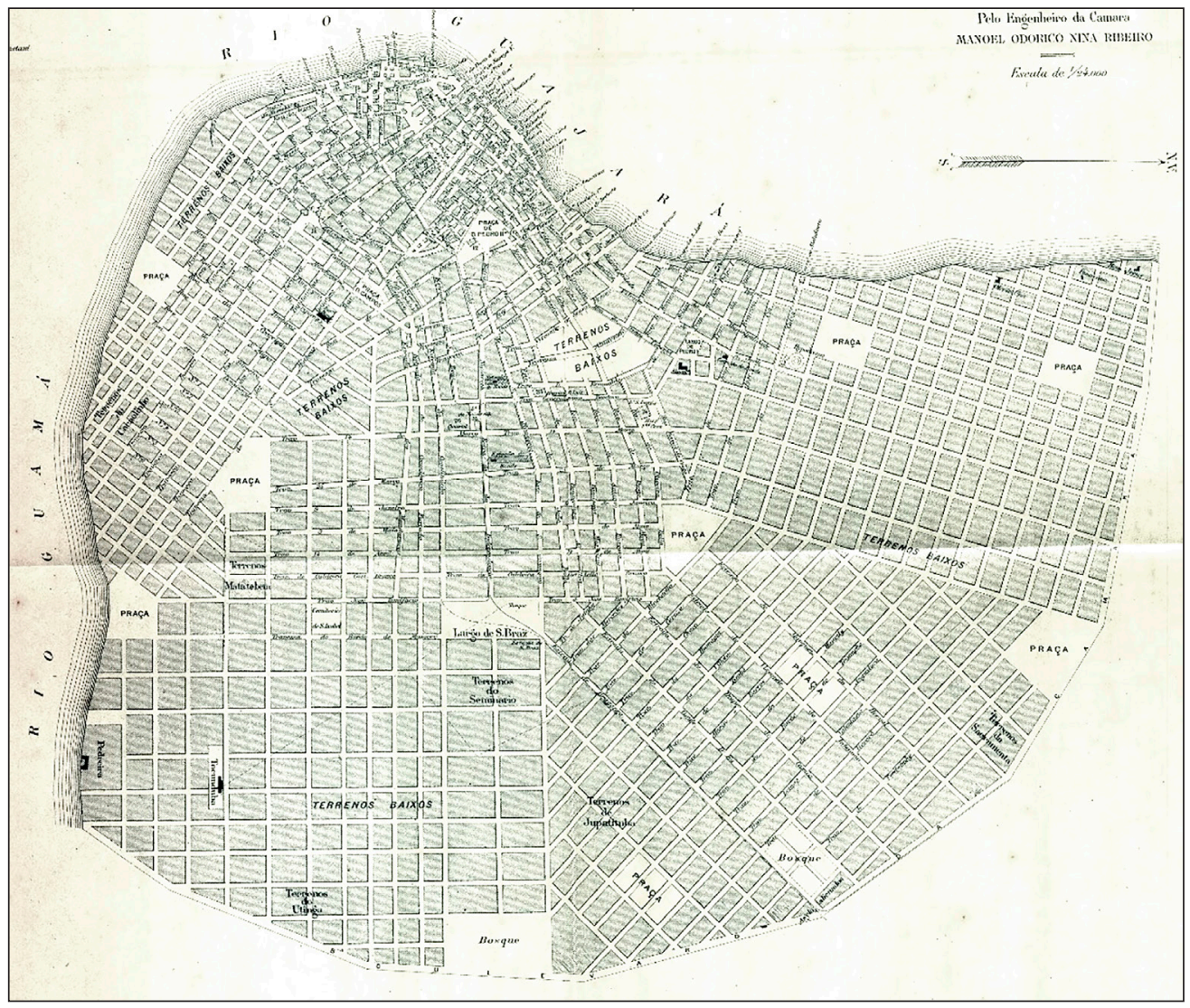

Figura 1 - Planta de Belém com plano de expansão da cidade. Nina Ribeiro (c. 1883-1886). Fonte: Muniz (1904).

A formulação consensualmente reproduzida pela historiografia é a de que a execução do projeto de Nina Ribeiro somente ocorreria cerca de vinte anos depois, durante o governo do intendente Antônio Lemos. Contudo, a pesquisa nos documentos de aforamento mostra que no final da década de 1860 já havia terrenos aforados ao longo da Estrada de Bragança, e que estes se inseriam em uma malha viária muito similar à existente no plano de Nina Ribeiro. Além disso, os alinhamentos dos terrenos no local se deram principalmente a partir da década 1880, evidenciando que a implantação do traçado não foi executada no governo Lemos. ${ }^{51}$ Os resultados dessas pesquisas mostram que, para além do foco na modernização urbanística, ${ }^{52}$ a expansão da cidade foi pautada e condicionada pela apropriação da terra, em uma iniciativa articulada de arruamento e parcelamento do solo pela Câmara Municipal, que será discutida neste artigo.
51. Cf. Cruz (1973); Duarte (1997a, 1997b); Lobato (2005).

52. Sobre a relação do Plano de Expansão de Belém com o processo de modernização urbana, cf. Duarte (1997b); Sarges (2000). 
53. O termo "gestão urbanística" refere-se aqui a diversas iniciativas públicas voltadas para estruturação e controle do espaço da cidade. Ainda que o conceito de urbanismo e os que dele derivam não estivessem estruturados nos primeiros séculos de ocupação da cidade, o entendimento do urbanismo como "conjunto de medidas técnicas, jurídicas e econômicas que permitem uma intervenção ou desenvolvimento autônomo das cidades" (Cf. Lepetit, 1988, p. 35 apud Fonseca, 2012, p. 90) mostra que a prática já era recorrente na administração citadina.

54. Cf. Moudon (1997).

55. Cf. Lima (1990); Marx (1991).

\section{IMPACTOS DA LEI DE TERRAS NA GESTÃO URBANÍSTICO-FUNDIÁRIA}

\section{Precedentes: instrumentos legais da gestão urbanístico-fundiária das terras de Belém}

Município era responsável pela própria gestão fundiária e urbanística. ${ }^{53}$ A gestão fundiária consistia em conduzir ações de concessão/aforamento de terra e legitimar ocupações dentro de seu patrimônio. A urbanística, por sua vez, consistia na orientação dos elementos físicos da ocupação da cidade, como abertura de ruas e regulamentação dos aspectos construtivos das edificações. Essas gestões chegavam a se confundir nas ações de aforamento de terrenos e, principalmente, nos atos de alinhamento de vias e edificações, em que se efetuava distinção jurídica e espacial entre o espaço público (via) e o privado (terreno particular), o que torna as ações de gestão bastante significativas para o estudo da morfologia urbana. ${ }^{54}$

Essa relação de mútua conformação entre aspectos urbanísticos e fundiários é intrínseca ao processo de formação das cidades, pois essencialmente uma cidade é composta por terrenos, lotes e glebas intercomunicados por vias de acesso. Essas unidades são conformadas juridicamente pelos direitos de posse ou propriedade de seus detentores, que lhes garantem o domínio de fato ou de direito sobre aquela determinada porção do espaço; mas também são conformadas espacialmente pela ocupação e pelos limites espaciais da área sobre a qual o ente exerce domínio (legal, baseado no direito garantido, ou ilegal, baseado na apropriação à margem da lei). Assim, a estruturação do espaço urbano está calcada na apropriação da cidade pelos diversos agentes, em um movimento que é, ao mesmo tempo, espacial e fundiário, pois não há delimitação espacial sem processo jurídico que a legitime ou a negue, tampouco uma atribuição de direito de domínio sobre a terra sem que se estabeleçam os limites dentro dos quais esse domínio será válido.

Nesse contexto, vale destacar que o domínio legal sobre a terra pode ter uma espacialização virtual, isto é, pode constar nos documentos legais sem necessariamente encontrar correspondência no espaço da cidade. Numa época em que os instrumentos de medição fundiária eram precários, ${ }^{55}$ e em que havia abundância de terras, os termos de aforamento eram vagos quanto à localização e delimitação espacial dos terrenos. Muitas vezes as terras aforadas não eram ocupadas de fato, criando-se uma divisão fundiária sem rebatimento espacial concreto. 
Assim, terrenos ocupados com base nos termos de aforamento (que muitas vezes eram imprecisos quanto a localização e dimensões do lotel deviam ser "arrumados", ou seja, ter seus limites precisamente definidos, tanto in loco, com a demarcação física, quanto juridicamente, com o registro de suas corretas dimensões e confinantes. Como se depreende das ações realizadas na cidade de Belém, o ato da arrumação era responsável, portanto, pela conformação física e jurídica dos limites do terreno aforado. Esse ajuste deveria acontecer por meio de uma correta delimitação da área com os terrenos adjacentes, inclusive áreas públicas de uso comum, como as vias, mediante ato de "alinhamento". Esse ato consistia justamente em estabelecer uma linha, clara e precisa, para dividir e delimitar o privado e o público. ${ }^{56}$ Portanto, as atividades de arrumar e alinhar estavam intimamente relacionadas, referindo-se à definição de limites dos terrenos. ${ }^{57}$

Nesse contexto, o Município assume papel de agente coordenador e até orientador do processo de estruturação urbana, seja através da abertura e alinhamento de vias, atribuição própria dos Municípios, 58 ou do aforamento de terrenos (e legitimações de ocupações ilegais, como será visto adiante) dentro da área de seu patrimônio fundiário. Nessas áreas, a possibilidade de intervenção da Câmara no espaço urbano se amplia, por meio da conjugação das ações de partilha da terra com as iniciativas de arruamento e alinhamento de vias e terrenos.

\section{instrumento aforamento}

A Câmara Municipal, enquanto detentora de uma sesmaria podia alienar as terras do seu patrimônio conforme the fosse conveniente. Apesar de existir a possibilidade de venda, era de praxe que os Concelhos Municipais aforassem os terrenos, alienando apenas o domínio útil da terra e permanecendo como senhorio direto, estratégia que thes garantia um rendimento anual utilizado para suprir despesas da Câmara. ${ }^{59}$ Assim, a enfiteuse foi o instrumento recorrentemente utilizado pelas Câmaras para a concessão de terras do seu patrimônio.

Os primeiros aforamentos eram feitos por meio de pregão, como determinavam as Ordenações Filipinas, ${ }^{60}$ conjunto de leis portuguesas transposto para a colônia brasileira. Nessa modalidade, a concessão era realizada após o pregão, e arrematava o terreno quem se dispusesse a pagar mais por seus foros anuais. Em Belém, o pregão continuou sendo utilizado até os primeiros anos do período imperial, como mostram os documentos registrados nos livros de termos de aforamento $^{61}$ da cidade.
56. Cf. Marx (1991, 1999); Lapa (1996).

57. O termo "alinhamento" e os que dele derivam são comumente referenciados na literatura sobre cidades portuguesas e brasileiras (Cf. Lapa, 1996; Marx, 1999) e são diretamente relacionados com o trabalho do arruador, responsável por abrir e alinhar as vias (Cf. Figueiredo, 1913; Lapa, 1996). O termo "arrumação" e seus derivados são utilizados nos documentos de alinhamento da cidade de Belém, e seu derivado "arrumador" também aparece na literatura sobre a cidade (Cf. Berredo, 1749; Cruz, 1999). Entretanto, não foram encontradas referências ao termo "arrumação" ou similares em relação a outras cidades. Esse assunto será mais bem discutido na seção "Os instrumentos alinhamento e arrumação".

58. Cf. Brasil (1828); Miranda (2000).

59. Cf. Abreu (1997); Freitas (2003); Glezer (2007a).

60. Cf. Almeida (1870).

61. Em Belém, os termos são organizados em livros de registros que englobam certo período; contudo, é comum um mesmo intervalo de tempo ser contemplado em mais de um livro. Desde o final do século XVIII até a década de 1930, os livros apresentam numeração sequencial até o $\mathrm{n}^{\circ} 25$, e oito desses livros não foram localizados nos arquivos da Codem. Os dezessete livros existentes no acervo da Codem reúnem cerca de 4600 termos de aforamento. 
62. Devido à inexistência de alguns livros de aforamento, não é possível afirmar o período exato em que o aforamento por pregão deixou de ser praticado. Pode-se supor, ainda, que o pregão tenha permanecido por algum tempo como estratégia para concessão de terrenos mais bem localizados e mais disputados.

63. Belém (1850-1870b, f. 82).
Contudo, observou-se que no século XIX o aforamento do terreno passou a ser realizado após avaliação da Câmara sobre a solicitação do particular, sem que o terreno fosse colocado em pregão. ${ }^{62} \mathrm{Em}$ grande parte dos casos, o tamanho e a localização do terreno eram sugeridos pelo requerente, que aguardava a aprovação de seu pedido pela Câmara. É interessante notar que as petições apresentam os mais variados argumentos para que a solicitação do particular fosse atendida, havendo desde justificativas pessoais até compromissos de trazer benefícios para a cidade:

O supplicante espera que à vista do que deixa espendido, e mais ainda pela consideração de ser elle chefe de família; ter servido ao pais e a frente de trinta annos nos differentes empregos e cargos que há exercido por nomeação do governo ou pelo voto do povo, e finalmente por se achar nas circunstancias de beneficiar o terreno que requer [...]. ${ }^{63}$

À Câmara, por sua vez, cabia decidir o tamanho e a localização que de fato seriam aforados, já que era necessário levar em conta, por exemplo, a existência de outros terrenos confinantes com o solicitado e, em alguns casos, a própria intenção pública de estabelecer uma morfologia específica no local, com quadras e lotes definidos (Figura 2).
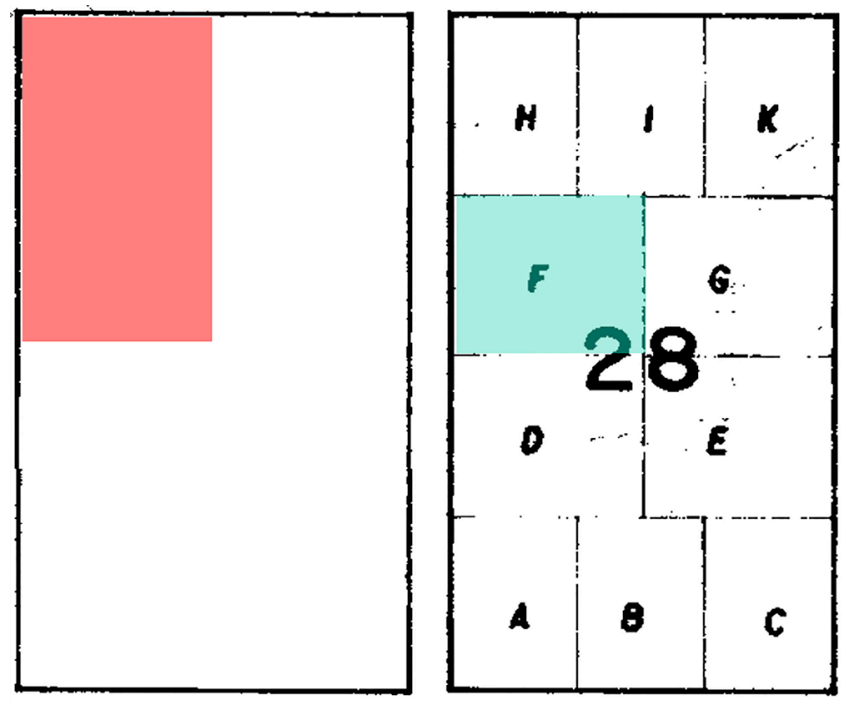

Figura 2 - Comparação entre a forma do terreno solicitado por Antônio Valente Cordeiro da Luz lem vermelho) e as forma do terreno aforado pela Câmara Municipal (em verde), na área parcelada no entorno da Estrada de Bragança. Fonte: Elaborado pelos autores a partir dos termos de aforamento da Câmara Municipal de Belém (Belém, 1869a, f. 13) e da Planta de Loteamento do Bairro da Pedreira. Acervo da Companhia de Desenvolvimento e Administração da Área Metropolitana de Belém. 
Observa-se que a Câmara poderia definir a forma do terreno de diversas maneiras: a primeira delas, utilizada principalmente nos primeiros séculos de ocupação, era a definição precisa apenas da frente do terreno, sendo os fundos designados em relação, por exemplo, a um curso d'água ou a um terreno já existente. ${ }^{64}$ Os trechos a seguir ilustram casos como esses:

Luiza Valeria de Olvr. ${ }^{\circ} 7$ braças de Choens $p$ detras da lgreja de S. Joao hindo $p$ o Piry á mao' esquerda: arrematados em 24 de outubro de 1759 pela q. ${ }^{\text {tia }}$ annualm. ${ }^{e}$ de $400 r^{s}$. L ${ }^{\circ}$ $1^{\circ}$ de arremataçoens ff $51 v^{\circ} .05$

Policarpo Antonio da S.a 4 Braças de Choens de sobra que ficam fazendo frente para o largo do Pôsso do Povo e com os fundos pegando nos ditos Choens des cazas de Manuel Duarte, correndo $p^{a}$ os fundos de Sargento Mór Antonio Martins: arrematados em [ilegível] de junho de 1770 p. ${ }^{\circ}$ quantia annual de 400 reis sendo fiador o Alffes. Luis da Costa L $2^{\circ}$ de arremataçoens fl 41 v. ${ }^{60}$

Como pode ser observado nesses documentos, os terrenos urbanos eram aforados em braças (sendo uma braça equivalente a cerca de 2,2 metros), diferentemente das sesmarias, que eram concedidas em léguas (cada légua equivalente a seis quilômetros). ${ }^{67}$ A clareza sobre as unidades de medida permite perceber a diferença de escala entre os dois tipos de concessão fundiária.

Pode-se observar também que, apesar de recorrentemente a dimensão dos fundos ser omitida dos termos de concessão, algumas vezes as dimensões dos terrenos eram designadas como "braças em quadra", o que significava que a frente e os fundos do lote apresentavam a mesma dimensão linear: "Valentim Gomes 30 braças de terra em quadra junto ao pau d'agua q' principião junto a caza da polvra novam. e feita: arrematados em 3 de dezembro de 1760 pela $q^{\text {tia }}$ annualm. ${ }^{e}$ de $950 \mathrm{r}^{\prime \prime} .68$

Vale ressaltar que naquele momento os foros eram cobrados de acordo com a medida da testada do terreno, mesmo quando a área era definida no termo de aforamento. Quando a terra requerida pelo suplicante estava encravada entre dois terrenos já concedidos, a definição das dimensões do lote a ser aforado era feita por meio do levantamento in loco das medidas da área disponível, como se observa:

Roberto Hesketh Sobrinho, requer a Vossas Senhorias the concedão por aforamento[... ]uma sobra de terrenos devolutos ao lado occidental da travessa quatorze de Março que intestão com os fundos de seus terrenos na travessa dois de Dezembro, sujeitando-se ao foro que pagão os outros posseiros nessa localidade[...].

O terreno que o Supplicante quer por aforamento está sem posseiro e entre as ruas João Balbi e Boaventura da Silva. Agrimensor [ilegível]. Secretaria da Camara Municipal do
64. Cf. Glezer (2007a); Marx (1991,1999).

65. Belém (1752-1877a, f. 6).

66. Belém (1752-1877c, f. 8).

67. Sobre as diferenças entre concessões de chãos urbanos e sesmarias, cf. Abreu (1997); Ribeiro (2017).

68. Belém (1752-1877b, f. 6, grifo nosso). 
69. Belém (1850-1870a, f. 62).

70. Marx (1991)

71. Comisso: "Multa, pena, em que incorre o que falta a certas condições, impostas por um contrato ou por uma lei" (Cf. Figueiredo, 1913, p. 486).
Pará, vinte e dois de Maio de mil oito centos sessenta nove. O Secretario João Severino Rubens de Mattos - $\bigcirc$ terreno que o Supplicante pede por aforamento está devoluto como tendo verificado pelas medições por mim feitas nessa localidade, estende-se este terreno desde a rua João Balbi para o norte onde começa o terreno dos herdeiros do Barão de Jaguarary a começar do terreno do Supplicante até a Travessa quatorze de Março. Estou que o supplicante merece ser deferido. Vossas Senhorias julgarão no intento como parecer de justiça. Compreende o terreno numa área de ter mil sete centos e setenta braças quadradas. Mede de frente pela travessa quatorze de Março sessenta braças com quarenta e cinco de fundo pelas ruas João Balbi e Boaventura da Silva, e mais trinta de frente pela mesma travessa até os terrenos dos herdeiros do Barão de Jaguarary, quarenta e nove de fundos até os terrenos do suplicante. ${ }^{69}$

Segundo Murillo Marx, ${ }^{70}$ foi a partir da segunda metade do século XIX que a definição tanto das frentes quanto dos fundos do terreno passou a ser uma constante nas concessões enfitêuticas. Na cidade de Belém observou-se que, com a importância conferida à definição dos fundos do terreno para a organização da partilha da terra, os foros passam a ser cobrados não mais em relação à dimensão linear da testada, mas à área do lote. Além disso, cabe destacar que as dimensões dos terrenos poderiam ser estabelecidas levando em consideração apenas o eixo das ruas ou uma divisão planejada do quarteirão em lotes, dentro de iniciativas de loteamento promovidas pela Câmara Municipal, como ocorreu no século XIX.

Após a definição da localização e das dimensões do terreno concedido, os termos de aforamento apresentam as cláusulas do contrato enfitêutico. As cláusulas correspondem, em geral, aos atributos do instituto jurídico da enfiteuse, como obrigatoriedade de uso, pagamento do foro e do laudêmio e proibição de alienação do bem sem prévia consulta ao senhorio (Quadro 1). Caso as cláusulas do contrato não fossem cumpridas, seriam aplicadas as penas de comisso ${ }^{71}$ e de devolução do terreno à Câmara, extinguindo-se assim o aforamento constituído.

Quadro 1 - Atributos do sistema enfitêutico expressos nas cláusulas dos termos de aforamento expedidos pelo Câmara do Município de Belém

\begin{tabular}{|l|l|l|}
\hline $\begin{array}{l}\text { Atributos do Sistema de } \\
\text { Aforamentos }\end{array}$ & \multicolumn{2}{|l|}{ Cláusulas do contrato } \\
\hline Pensão anual; & Cláusulas 1 e 2 & $\begin{array}{l}\text { 1. a de pagar elle emphyteuta o referido foro } \\
\text { em moda corrente d'este Imperio, e o direito } \\
\text { dominal de um laudêmio correspondente } \\
\text { á dois e meio porcento; 2. a de fazer este } \\
\text { pagamento na Secretaria da Camara dentro } \\
\text { de cada anno civil; }\end{array}$ \\
\hline
\end{tabular}




\begin{tabular}{|c|c|c|}
\hline $\begin{array}{l}\text { Autorização do senhorio } \\
\text { para alienação do bem }\end{array}$ & Cláusula 3 & $\begin{array}{l}\text { 3. }^{a} \text { de não fazer venda, doação, } \\
\text { transacção, permutação, cessão, divisão, } \\
\text { penhor, hypotheca, constituição de } \\
\text { servidão, doacção em pagamento, cessão } \\
\text { emphyteutica ou outra qualquer alienação } \\
\text { de forma ou maneira alguma sem prévia } \\
\text { audiência e expresso consentimento da } \\
\text { Camara Municipal como directa senhoria; }\end{array}$ \\
\hline Utilização do bem & Cláusula 4 & 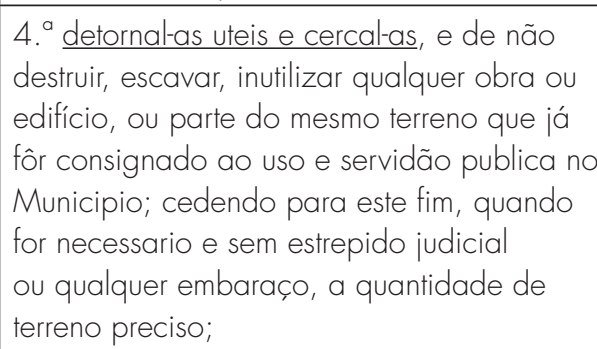 \\
\hline Pena de Comisso & Cláusula 5 & $\begin{array}{l}\text { 5. a finalmente, de incorrer elle emphyteuta } \\
\text { nas penas de comisso e de devolução à } \\
\text { mesma Camara no caso de faltar a algumas } \\
\text { d'estas condições. }\end{array}$ \\
\hline
\end{tabular}

Fonte: Elaborado pelos autores a partir dos termos de aforamento da Câmara Municipal de Belém (Belém, 1869e).

Cabe destacar que a cláusula quarta apresenta disposições que vão além das formalidades estritas do sistema de aforamento, passando a incluir normas do que hoje é considerado direito urbanístico, como a instituição da servidão pública. Segundo o texto, se já houvesse servidão instituída, o instituto do aforamento deveria adequar-se a ela; caso o Município desejasse estabelecer servidão dentro do lote já aforado, o enfiteuta deveria ceder o terreno sem resistências. Assim, observa-se com essa cláusula que o Município tira partido de sua prerrogativa enquanto detentor do domínio direto da terra para restringir o direito do enfiteuta, limitando o direito privado de uso e ocupação do terreno em prol do interesse municipal de estabelecer um logradouro público no local.

Os arruamentos realizados pela Câmara Municipal na área de expansão da cidade, por exemplo, avançavam sobre as terras dos herdeiros do Dr. Joaquim Guimarães, ${ }^{72}$ criando uma benfeitoria de fruição pública que beneficia a coletividade - a via. Por outro lado, essa benfeitoria urbaniza e valoriza o terreno do particular, criando faces de quadra servidas pelas vias públicas que mais tarde seriam dotadas de infraestrutura, tornando-se ainda mais valorizadas.

Na cidade de São Paulo, onde o patrimônio municipal coexistia com terrenos de propriedade particular, os arruamentos empreendidos pelo Município exigiam incialmente a indenização do proprietário de áreas desapropriadas para 
73. Cf. Simoni (2009).

74. Para verificar as mudanças do significado da palavra alinhamento, cf. Marx (1999).

75. Silva (1890, p. 136). o arruamento ou, em segundo momento, a contrapartida da isenção de tributos e obrigações do proprietário. Mais tarde, no início do século XX, a lei paulistana de abertura de ruas transfere ao proprietário a responsabilidade pelo planejamento (sujeito à aprovação municipal) e execução dos arruamentos, conferindo ao particular maior poder na estruturação urbana..$^{73} \mathrm{Em}$ Belém, entretanto, nota-se que a posição de senhorio da Câmara Municipal sobre as terras aforadas, bem como sua prerrogativa de estabelecer as cláusulas e condições do aforamento, agregam maior liberdade de atuação à Câmara, enquanto gestora dos aspectos urbanísticos da cidade.

Portanto, em Belém, a concessão de um terreno através do instituto do aforamento no século XIX pode ser considerada um processo de "mão dupla", iniciado a partir do requerimento do suplicante e efetivado de acordo com a definição daquele que concede a terra, no caso, a Câmara Municipal. Logo, ainda que os particulares pudessem especificar a testada ou área do terreno que intentavam receber, as características morfológicas dos lotes concedidos por aforamento dentro do patrimônio municipal foram determinadas, em última instância, pela Câmara Municipal, que poderia aprovar a sugestão do peticionário ou adequá-la a seus propósitos para a ocupação da cidade, caso existissem. Dessa forma, o Município concentrava não apenas o poder de conceder terras, mas também a prerrogativa de organizar a ocupação da cidade por meio dessa distribuição, uma vez que era responsável por definir as dimensões e a localização dos terrenos que aforava.

\section{Os instrumentos alinhamento e arrumação}

Com a Lei de Terras e a instituição da distinção entre terras públicas e privadas, a delimitação entre os terrenos, bem como entre estes e as vias públicas, passa a ser mais contundente. Desse modo, aumenta a demanda por alinhamento e demarcação dos terrenos aforados. Até o século XVIII, o principal sentido das palavras "alinhar" e "alinhado" estava relacionado à compostura e decência. Em segundo plano aparecia o sentido de dispor em linha reta para tomar medidas referentes ao trabalho de carpinteiros e pedreiros. Foi somente no século XIX que esses termos passaram a aparecer nos dicionários portugueses com referência principal ao alinhamento de vias e ao ordenamento urbano:74 "Alinhamento, s.m. Acção de alinhar, de pôr em linha recta, tirar ao cordel. § O lançamento, ou linha, em que está lançada uma rua, um muro [...], não attendendo aos angulos, mas a direcção da maior parte". ${ }^{75}$ Assim, apesar de o alinhamento ser uma técnica 
utilizada para arruação desde o século XVIII em Portugal (designada pelo termo "cordeamento"), foi no século XIX que passou a ser uma das mais importantes formas de controle administrativo das edificações por parte do Município.76

Além da função urbanística de garantir o ordenamento da via e sua disposição em uma linha reta, o alinhamento possuía a importante função de estabelecer o limite espacial entre a terra privada (o terreno) e a terra pública (a via). ${ }^{77}$ Essa divisão é principalmente necessária considerando a especialização funcional característica do urbanismo português, na qual cabe ao governo a estruturação dos espaços públicos e da infraestrutura urbana, e ao cidadão a construção dos prédios particulares. ${ }^{78} \bigcirc$ alinhamento dos terrenos se torna ainda mais necessário conforme a cidade é adensada e as terras disponíveis para ocupação tornam-se escassas e, consequentemente, disputadas por diversos atores sociais. Nessa condição, o alinhamento tornava-se interesse não só do poder público, mas do próprio detentor das terras.

A responsabilidade de realizar o alinhamento cabia ao profissional conhecido como "arruador", que tinha tanto a função de abrir as ruas quanto de estabelecer seu alinhamento, ${ }^{79}$ como pode ser observado no trecho a seguir:

A abertura de ruas, seu traçado, demarcação e construção cabiam ao arruador, cargo exercido antigamente por construtores locais, para o qual passaram a ser escolhidos profissionais competentes, como engenheiros, arquitetos $e$, na falta destes, mestres carpinteiros, dado que estes profissionais sabiam manejar instrumentos de medição. [...]. Ao arruador competia ainda o alinhamento de ruas e becos [...], portanto, a simetrização do conjunto edificado em relação aos espaços que o intervalam, objetivando o ordenamento funcional, econômico, social e estético que a sociedade local vai passando a exigir. ${ }^{80}$

As pesquisas nos documentos de alinhamento de Belém mostram que nessa cidade o "arrumador" 81 era o agente responsável tanto pelo alinhamento das vias, quanto pela arrumação e demarcação dos terrenos, ações que visavam delimitar in loco o terreno do particular e distingui-lo de seus confinantes.

Assim, na literatura sobre questões urbano-fundiárias costuma-se encontrar referências aos processos de alinhamento e demarcação de terrenos, mas sem uso dos termos arrumação ou arrumador, utilizados em Belém. Esses termos trazem não apenas a ideia de demarcação do terreno, mas a noção de conformação espacial do direito sobre a terra e de adequação dos limites, expressando mais profundamente a abrangência e importância do processo.

Por outro lado, documentos da Câmara de São Paulo mostram que nessa cidade cabia também ao arruador (ou alinhador) verificar a situação fundiária do
76. Cf. Monteiro (2010).

77. Cf. Marx (1991, 1999); Monteiro (2010).

78. Cf. Monteiro (2010).

79. Cf. Figueiredo (1913); Lapa (1996).

80. Lapa (1996, p. 41-42).

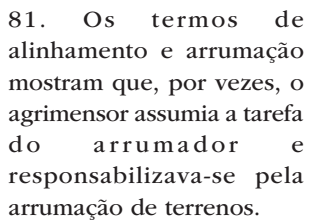


82. São Paulo (1939, p. 165 e 257).

83. Berredo (1749, p. 568).

84. Cf. Guimarães (2006).

85. Cruz (1973, p. 198).

86. Cruz (1973, p. 199). terreno, desempenhando função similar à do profissional arrumador, corroborando a ideia de que as atividades de arruar, alinhar, arrumar e demarcar estavam intimamente relacionadas e eram articuladas:

Uma petição de Vicente Marianno do Nascimento, pedindo uma data de terreno no lugar denominado Quatinga em terreno devoluto deste município. Despacho: Ao arruador para informar. Santo Amaro 27 de Maio de 1891. Padre Luiz Bittencourt. Informação do alinhador: Informo que é devoluto o terreno que o suplicante solicita. Santo Amaro 1 de Junho de 1891. O Alinhador Guilherme Belfort [...].

Uma petição de Adriano Sepore, pedindo uma data na quadra de oitenta reis o metro quadrado. Despacho: Concedo. Ao arruador para determinar-the a data que estiver devoluto. Santo Amaro 8 de Maio de 1891.82

A atuação do arrumador em Belém remonta aos primeiros anos da ocupação da cidade. Destaca-se, por exemplo, o papel desse profissional na conformação da rua São Vicente (atual Travessa Manoel Barata) em 1676, a fim de organizar a instalação dos colonos açorianos que chegavam à cidade:

Os moradores do Pará, generosamente compassivos, distribuiraõ toda aquella gente pelas suas casas [...]; para o que em 22 do mez de Janeiro the repartiraõ chãos com bastante largueza no sitio da Campina [...], por ordem, e assistência do Senado da Camara, que mandou tambem ao Arrumador os pozesse logo em forma de rua, a que se deu o nome de S. Vicente $[\ldots] .{ }^{83}$

Já no século XIX, a atuação do arrumador viria a ser reforçada pelas Posturas Municipais, elaboradas entre 1829 e 1831, que forneciam disposições legais para ordenamento e fiscalização do espaço público da cidade. ${ }^{84}$ Provavelmente no mesmo ano, a Câmara Municipal contrata o italiano Gaudêncio Ponciotti para o cargo de arrumador da cidade, "em virtude dos seus conhecimentos de arquitetura civil". ${ }^{85}$ Essa contratação "era do que precisava Belém, naquele primeiro quartel do século XIX, para desenvolver-se dentro do plano urbanístico que the haviam traçado os administradores provinciais". ${ }^{80}$ Observa-se, portanto, a relevância da arrumação - e, por consequência, do alinhamento, com o qual estava atrelada para a implantação de planos urbanísticos, na medida em que garantia a espacialização do planejamento.

Até a primeira metade do século XIX, os documentos de demarcação de terrenos na cidade de Belém foram os Autos de Vistoria, Medição e Arrumação que fazem os Senhores do Nobre Senado, nos quais constava apenas a figura do 
profissional arrumador, e não de uma comissão. Entretanto, nos documentos a partir da segunda metade do século, os trabalhos de alinhamento e arrumação passam a ser desempenhados pela Comissão Arrumadora da Municipalidade, ${ }^{87}$ levando à suposição de que esta tenha sido instituída em virtude do aumento na demanda por tais procedimentos no período.

De início, os documentos que atestam as arrumações realizadas por essa Comissão eram identificados como "termos de medição e arrumação", posteriormente denominados "termos de arrumação e alinhamento". Isso evidencia mais uma vez que a arrumação e o alinhamento eram feitos de modo conjugado, porque tais procedimentos possuem função similar: tornar os limites do terreno mais precisos - tanto espacialmente, por meio da demarcação física, quanto juridicamente, de modo a dirimir conflitos de propriedade entre os foreiros e entre estes e o Município.

Pode-se supor que, principalmente nas áreas de ocupação menos consolidada, a ausência de pavimentação das vias e a ocupação rarefeita dos terrenos tornasse a distinção entre rua e lote pouco definida. Logo, realizar o alinhamento era fundamental para estabelecer o limite da rua e evitar que o terreno do foreiro invadisse a área pública. No trecho extraído de um jornal do século XIX ficam evidentes as responsabilidades e a atuação da Comissão Arrumadora nesse sentido:

mesmo sr. presidente, continuando com a palavra, diz que tendo-se reconhecido ser pequeno o espaço de cinco braças de largura dado ás ruas e travessas do Piry, resolveo a camara em sessão de 16 de dezembro de 1869, que as referidas ruas e travessas tivessem a capacidade de dez braças, deixando as cercas e casas que ahi ficam fora do alinhamento dado, até que ellas tenhão de ser construídas ou reparadas pelos seos donos, que nessa occasião serião obrigados a recual-as. Entretanto, a comissão arrumadora tem consentido construir-se casas, e levantar se cercas, deixando as ruas com cinco braças, e algumas até com tres, como nos fundos da rua Longa. Pede portanto providencias terminantes com o fim de obstar a continuação de similhante abuso.

O sr. João Diogo é de opinião que se ordene á commissão arrumadora que colloque marcos visíveis que mostrem o rumo que devem ter as ruas; que os cercados sejão recuados e casas medidas na parte que obsta o alinhamento dado, afim de serem desapropriadas, ficando a mesma commisão responsável pela transgressão desta deliberação. ${ }^{88}$

Além disso, à medida que o foreiro investia e realizava benfeitorias no terreno, valorizando-o de certa forma, a necessidade de alinhamento e demarcação tornava-se mais contundente para ele, como pode ser observado no argumento de um dos foreiros da Câmara: "desejando beneficiar o terreno [...] vém pedir-vos que
87. Os termos de alinhamento e arrumação mostram que, aproximadamente na década de 1920, a comissão arrumadora tornou-se "Commissão d e alinhamentos, arrumações de terrenos e aviventação de marcos". Atualmente os alinhamentos são realizados por um departamento da Secretaria de Urbanismo (Seurb).

88. Cf. O Liberal do Pará (1871, p. 1). 
89. Belém (1900-1902a, f. 53).

90. Belém (1902-1905, f. 66).

pela Commissão arrumadora seja dado o respectivo alinhamento". 89 Assim, o processo de alinhamento e arrumação de terrenos partia da iniciativa do próprio foreiro, que solicitava à Municipalidade a execução do alinhamento. A petição era apresentada ao presidente da Câmara (ou intendente municipal, na República) e a condição primordial para deferir a solicitação era o pagamento atualizado dos foros.

Com o deferimento da solicitação de alinhamento, a Comissão Arrumadora publicava em edital o dia designado para a arrumação, para que os confinantes do terreno pudessem comparecer ao local a fim de dirimir possíveis contestações na demarcação. $\bigcirc$ eixo de referência para medição poderia ser estabelecido por outros terrenos já alinhados, ou pelos marcos do próprio quarteirão, caso existissem. Demarcavam-se então as terras sob domínio do foreiro, instalando-se marcos nos vértices do lote para distingui-lo dos terrenos vizinhos e das áreas públicas.

Nos termos de alinhamento, as descrições das medições aparecem ora mais sucintas, contendo somente a indicação das dimensões do terreno, ora mais detalhadas, com o registro de todo o processo de medição, como pode ser observado no trecho a seguir:

\footnotetext{
No quarteirão 25 no marco do cruzamento da Avenida Duque de Caxias e travessa Lomas Valentinas, foi installado [?] o instrumento e vizado [?] o marco do mesmo quarteirão, canto da travessa ltororó. A linha de divisa da corria[?] no rumo de $\left(40^{\circ}-30^{\prime} \mathrm{N}\right.$.E) e mediram-se, do instrumento para a frente $46<m>, 86, \mathrm{~cm}$, ou a frente do lote $\mathrm{A}$, e colocou-se um novo marco no limite. D'ali, na mesma estação, deo-se uma deflexão para a esquerda, correndo a visada no rumo de $\left(50^{\circ}-\mathrm{NW}[\right.$ ? ] ] e mediram-se para a frente $92<\mathrm{m}>, 40$, onde plantou-se novo marco. Instalado o instrumento n'essa [?] ultima balisa, no rumo de $\left(40^{\circ}, 30^{\prime} \mathrm{N}\right.$.E) tirou-se o comprimento de $46<\mathrm{m}>, 86, \mathrm{~cm}$ a linha de fundos e plantou-se novo marco. ${ }^{90}$
}

Como visto, em Belém, as ações de alinhamento eram acompanhadas da arrumação do terreno, sendo demarcado tanto o limite frontal do lote com a rua quanto os demais limites em relação aos terrenos adjacentes. É possível, portanto, perceber o destaque que o processo de arrumação recebe na cidade de Belém, sendo equiparado em relevância ao tradicional ato do alinhamento, presente tanto nas cidades portuguesas quanto nas brasileiras. Essa ênfase conferida à arrumação dos terrenos evitava divergências entre os documentos de posse e propriedade da terra (que atestam as dimensões do lote) e a ocupação de fato, garantindo os direitos dos ocupantes e também do Município, enquanto senhorio e agente regulador do espaço público (Figura 3). 


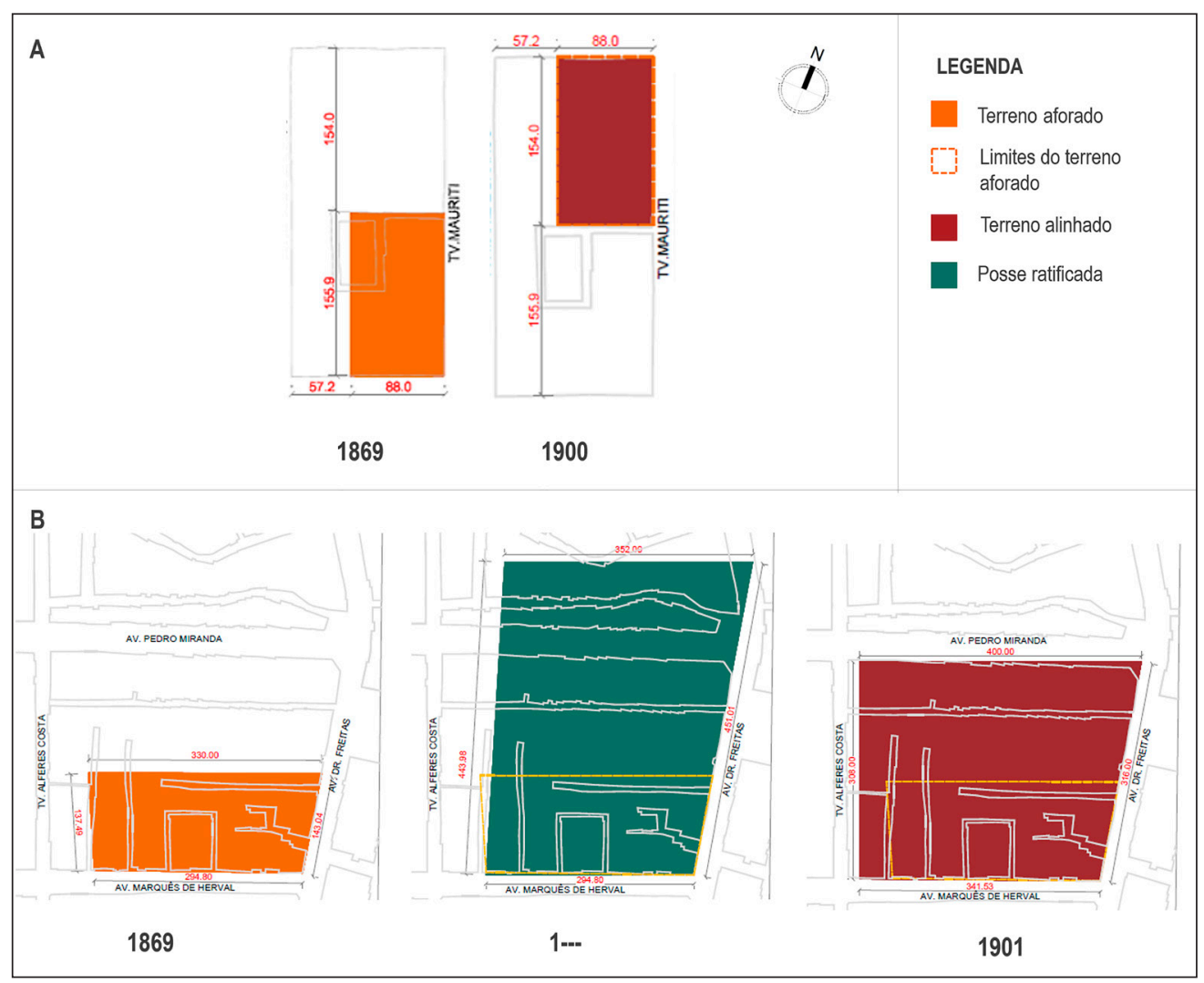

Figura 3 - Casos em que o alinhamento conferiu forma ou localização diferentes das apresentadas nos termos de aforamento. Na figura B, a área ocupada pelo foreiro (em verde) e ratificada pelo Câmara foi reduzida para respeitar os limites da quadra e o alinhamento da via. Fonte: Elaborado pelos autores a partir dos registros dos termos de aforamento (Belém, 1869c, f. 27; 1869d, f. 77) e de alinhamento e arrumação (Belém, 1900-1902a, f. 53; 1900-1902b, f. 169) da Câmara de Belém.

Observa-se então que o alinhamento e a arrumação eram instrumentos de caráter jurídico e morfológico, responsáveis tanto por espacializar os direitos dos particulares e do Município sobre a terra, quanto por ajustar a forma das vias e lotes da cidade. Além disso, muitas vezes o ato da arrumação também definia os limites dos terrenos, quando estes eram concedidos de forma imprecisa. Portanto, o estudo desses instrumentos é de grande relevância para entender a forma da cidade, em sua constituição fundiária e morfológica. A Câmara, como detentora da Primeira Légua Patrimonial, exercia o importante papel de direcionar a ocupação da cidade, por meio dos instrumentos de aforamento, alinhamento e arrumação. 
91. A lei estabelecia algumas exceções, como a possibilidade de concessão gratuita das terras localizadas em uma faixa de dez léguas a partir da fronteira com outros países.

92. Cf. Lima (1990).

93. Cf. Smith (1990)

\section{AÇÕES DA CÂMARA MUNICIPAL NO NOVO CONTEXTO FUNDIÁRIO}

Por meio da gestão que integrava ações de cunho fundiário e urbanístico, - Município já estruturava a ocupação da cidade desde os primeiros séculos após sua fundação. Contudo, o fazia de forma menos sistemática e em menor escala (em razão da própria demanda de ocupação) e dentro de um propósito mais voltado para uso/ocupação do que para comercialização de terras.

Como consequência de uma nova forma de lidar com a propriedade fundiária, em que o valor de troca começava a prevalecer sobre o valor de uso, o Município adota estratégias de divisão sistemática da terra em lotes - o loteamento. De outro lado, as ações municipais de legitimação das ocupações precárias estabelecidas dentro de seu patrimônio efetuam o processo de regularização fundiária dentro da sesmaria do Câmara, reverberando, no âmbito urbano, a política de regularização fundiária prevista pela Lei de Terras para as áreas rurais. Esses dois tipos de ação municipal sobre as terras urbanas - o loteamento e a legitimação das posses irregulares - trouxeram implicações para a definição da morfologia da cidade, como será visto a seguir.

A Lei de Terras, que instituía a propriedade fundiária privada no Brasil e determinava que o único meio de adquirir terra pública seria a compra, ${ }^{91}$ foi baixada pelo governo imperial após um período de ausência de regulação fundiária que perdurou de 1822 ano da suspensão do regime sesmarial, até 1850. Como as sesmarias concedidas a particulares pela Coroa Portuguesa constituíram-se em grandes porções de terra que permaneceram subutilizadas ao longo dos séculos, esse regime foi suspenso por meio da Resolução de 17 de julho de 1822.92 A resolução, entretanto, não dispunha sobre a situação das antigas sesmarias e nem descrevia como, a partir de então, as terras públicas passariam a ser transmitidas. Iniciou-se assim um período de ausência de regulação sobre as formas de apropriação do solo, que ficou popularmente conhecido como Regime de Posses. A partir desse momento a ocupação de terras por posseiros, ou proprietários senhoriais, prática que já existia desde o princípio da Colonização, intensificou-se. ${ }^{93}$ Assim, entre 1822 e 1850 o que orientou a forma de apropriação do solo rural não foi uma regulação, mas a oportunidade que a ausência de regulação oferecia.

Além da crise do sistema sesmarial e da conseguinte ausência de regulação fundiária, o Estado brasileiro era pressionado pela Inglaterra para que substituísse - trabalho escravo pelo trabalho assalariado, a fim de constituir mercado consumidor para a produção em larga escala propiciada pela Revolução Industrial, 
com consequências para a questão fundiária. Em 1838 inicia-se um debate na Câmara e no Senado sobre a questão das terras no Brasil, que dá origem ao projeto de lei denominado "Terras Devolutas e Colonização". Tal projeto articula questões da propriedade da terra com a iniciativa de introdução do trabalho assalariado. Os partidários dessa proposta acreditavam que a concessão de terras de forma gratuita ou por valores irrisórios constituía um empecilho para implantar o trabalho assalariado no Brasil. 94

Dessa forma, com a instituição da propriedade privada da terra e sua aquisição somente por meio de compra e venda, os imigrantes seriam condicionados a vender sua força de trabalho para que pudessem se tornar proprietários de um pedaço de terra. Além disso, era interesse da elite agrária do país que a renda oriunda da exploração da força do trabalho escravo, prestes a entrar em declínio, fosse substituída pela renda da privatização da terra.

Nesse contexto, em 4 de setembro de 1850 é suspenso o tráfico negreiro no Brasil, por meio da Lei Eusébio de Queiroz, dando início ao processo de substituição da mão de obra escrava pela assalariada dos imigrantes europeus. Em 18 de setembro de 1850 o projeto de lei "Terras Devolutas e Colonização" é aprovado, sendo promulgada a lei n 601 - a Lei de Terras.

Após o período sem regulação sobre a apropriação do solo e consequente proliferação de novas ocupações, a Lei de Terras prevê uma espécie de recenseamento das terras do país, a fim de regularizar a situação e estabelecer as terras que ainda não haviam sido apropriadas por particulares e que seriam devolvidas e reincorporadas ao patrimônio público - as chamadas terras devolutas. A partir dessa medida, estabelece-se uma distinção entre terras públicas e privadas anteriormente não existente, posto que até então todas as terras, ainda que concedidas aos sesmeiros, estavam submetidas ao domínio da Coroa. ${ }^{95}$

Conforme a lei, tanto as sesmarias não confirmadas por Carta Régia quanto aquelas que haviam caído em comisso por não atenderem as exigências legais poderiam ser revalidadas, caso comprovassem o cultivo da terra. As sesmarias já confirmadas, por sua vez, deveriam apenas ser registradas. Para as posses mansas e pacíficas constituídas há mais de quarenta anos, a disposição era que fossem reconhecidas e legitimadas. ${ }^{96}$ Nesse sentido, o período sem regulação (18221850) foi determinante para a formação de novos latifúndios rurais e para a multiplicação de ocupações irregulares. ${ }^{97}$

Assim, a lei outorgou a propriedade aos sesmeiros que estavam em conformidade com as disposições legais do regime sesmarial, bem como àqueles que haviam perdido seus direitos (mas permaneciam com a posse e o cultivo da
94. Cf. Smith (1990).

95. Cf. Lima (1990).

96. Cf. Brasil (1850).

97. Cf. Cardoso (2010); Smith (1990). 
98. Quando Igreja e Estado eram vinculados, as freguesias (ou paróquias) tornaram-se as unidades administrativas do registro, e o pároco tornou-se responsável pela inscrição, daí o nome do documento.

99. Cf. Brasil (1854).

100. Cf. Marx (1991).

101. Cf. Brasil (1850).

102. Cf. Glezer (2007b).

103. São considerados terrenos de marinha aqueles banhados pelas águas do mar ou dos rios navegáveis até a distância de quinze braças craveiras (33 metros) para a parte da terra, contadas desde o ponto a que chega a preamar média. Cf. Brasil (1868). terra) e aos demais posseiros. Uma vez regularizadas as sesmarias canceladas e as posses já constituídas, a compra torna-se o único meio para aquisição de terras públicas, sendo proibida a constituição de novas posses. A partir de então, a terra adquire caráter de mercadoria.

$\bigcirc$ decreto $n^{0} 1.318$, de 30 de janeiro de 1854, regulamentou as disposições da Lei de Terras e estabeleceu o Registro das Terras Possuídas lou Registro Paroquial, como ficou conhecido| ${ }^{98}$ para a discriminação dos chãos que já haviam sido apropriados, formal ou informalmente. ${ }^{99}$ Assim, todos os detentores ou possuidores de terra eram obrigados a registrar seus terrenos no período estabelecido pelo regulamento. A inscrição era realizada com base na declaração do seu possuidor, sem exigência de documento que confirmasse o direito do declarante sobre o terreno. Logo, esses registros não constituem fontes plenamente confiáveis sobre a situação fundiária do país à época.

Com essas medidas, teoricamente estariam definidas quais terras estavam sob domínio de particulares e quais eram públicas. Nas áreas rurais, a transmissão de terras públicas não deveria mais ser feita por meio de concessão ou doação, e sim através de compra e venda. Com a redução da possibilidade de alcançar um pedaço de chão por meio de uma concessão do governo, a terra - que agora poderia ser propriedade pública ou privada - adquire significativo valor de troca, um maior potencial de renda para seu detentor. Entretanto, essa transição do regime de posses para o de compra e venda se deu de maneira progressiva e contraditória: até as primeiras décadas do século XX persistiam na alienação das terras públicas práticas de concessão, aforamento e posse, junto com compra e venda. ${ }^{100}$

Contudo, a Lei de Terras ressalvava de suas disposições as sesmarias revalidadas e registradas e as áreas urbanas. ${ }^{101}$ As sesmarias dos Concelhos Municipais, por exemplo, uma vez registradas, permaneciam sob domínio do Município, e este mantinha seu direito de aforar terras. Persistia, com isso, o aforamento de terras e a propriedade bipartida nas cidades brasileiras, demonstrando a continuidade de legislações e práticas fundiárias do Antigo Regime no trato da propriedade urbana. ${ }^{102}$ Observa-se então que, mesmo com a suspensão do regime sesmarial, o período do regime de posses e a implantação da Lei de Terras, o instrumento jurídico do aforamento permaneceu como uma das mais estáveis formas de transmissão de terras particulares e públicas, sendo utilizado até hoje para alienação dos terrenos e acrescidos de marinha. ${ }^{103}$ Para os demais tipos de terreno, a constituição de novos aforamentos tornou-se proibida a partir de 2002, mas permaneceram válidos os atos previamente constituídos. 
As áreas urbanas que não estivessem incluídas nas sesmarias dos Concelhos continuavam sob domínio direto do Estado, para que este dispusesse sobre a destinação daquelas terras, podendo gerir a expansão de núcleos existentes ou a criação de novos. Como não havia clara definição do que era considerado como área urbana, o perímetro onde se recolhia o imposto da décima ${ }^{104}$ tornou-se sinônimo de área urbana em termos administrativos. Entretanto, é importante destacar que a delimitação para aplicação do imposto não considerava a ocupação efetiva da cidade, ${ }^{105}$ de modo que, na prática, esse perímetro considerado urbano poderia não corresponder, de fato, à área urbanizada da cidade.

Nesse sentido, o próprio decreto regulamentador da Lei de Terras excluía da obrigatoriedade do registro as áreas onde o imposto da décima urbana era cobrado. ${ }^{100}$ Em Belém, contudo, a Lei Provincial n³94, de 25 outubro de 1861 , estabeleceu que não haveria cobrança da décima urbana em locais onde eram cobrados aforamentos. Daí que, na área do patrimônio da Câmara de Belém, devido à não aplicação da décima urbana tornaram-se necessários os registros paroquiais para averiguar a situação fundiária, como dispunha a Lei de Terras. ${ }^{107}$

As principais repercussões da Lei de Terras foram o reconhecimento das ocupações informais, a instituição legal da propriedade privada da terra no país (desvinculando o particular do Estado) e a mudança no valor da propriedade fundiária, que passa de status social à mercadoria. Ainda que a lei não regulamentasse a ocupação das áreas urbanas, essa nova maneira de conceber a propriedade fundiária - baseada no reconhecimento do seu valor de mercado - consolida-se no decorrer do século e alcança as áreas urbanas, de modo que tanto senhorios quanto enfiteutas se interessam em deter o domínio absoluto de suas terras, podendo administrá-las mais livremente e auferir uma renda fundiária exclusiva decorrente de sua inserção no mercado de terras, que desponta com o crescimento dos núcleos urbanos no final do século.

\section{Loteamento, ratificação de posses e a configuração espacial do Plano de Expansão de Belém no século XIX}

A partir da segunda metade do século XIX, a Câmara Municipal de Belém implementou diversas iniciativas de parcelamento do seu patrimônio, em menor ou maior escala, valendo-se da propriedade fundiária para maximizar seu potencial de intervenção urbana e até mesmo gerando uma reserva fundiária para adensamento da cidade. Esses loteamentos foram responsáveis por ocupar novas
104. O imposto da décima urbana foi criado em 1808 pelo governo imperial e equivalia a $10 \%$ dos rendimentos líquidos dos bens de raiz urbanos. Cf. Bueno (2005).

105. Cf. Nascimento; Maia (2011).

106. Cf. Brasil (1854).

107. Cf. Oliveira; Fischer (2017). 
áreas da cidade e direcionaram a ocupação ao interior da Primeira Légua Patrimonial. A planta da cidade de Belém, levantada pelo engenheiro João de Palma Muniz e publicada em seu livro sobre os patrimônios dos concelhos municipais, ${ }^{108}$ apresenta a malha viária da cidade do início do século XX, ao mesmo tempo que identifica os loteamentos realizados pela Câmara e alguns terrenos particulares (Figura 4). Observa-se que os loteamentos municipais assinalados na planta de Palma Muniz aparecem na Plano de Expansão de Nina Ribeiro de 1883-1886 com a indicação dos topônimos existentes. Isso demonstra que a originalidade do projeto de Nina Ribeiro consiste no prolongamento da malha viária da cidade, que já incluía os arruamentos planejados pela Câmara Municipal em meados do século XIX.

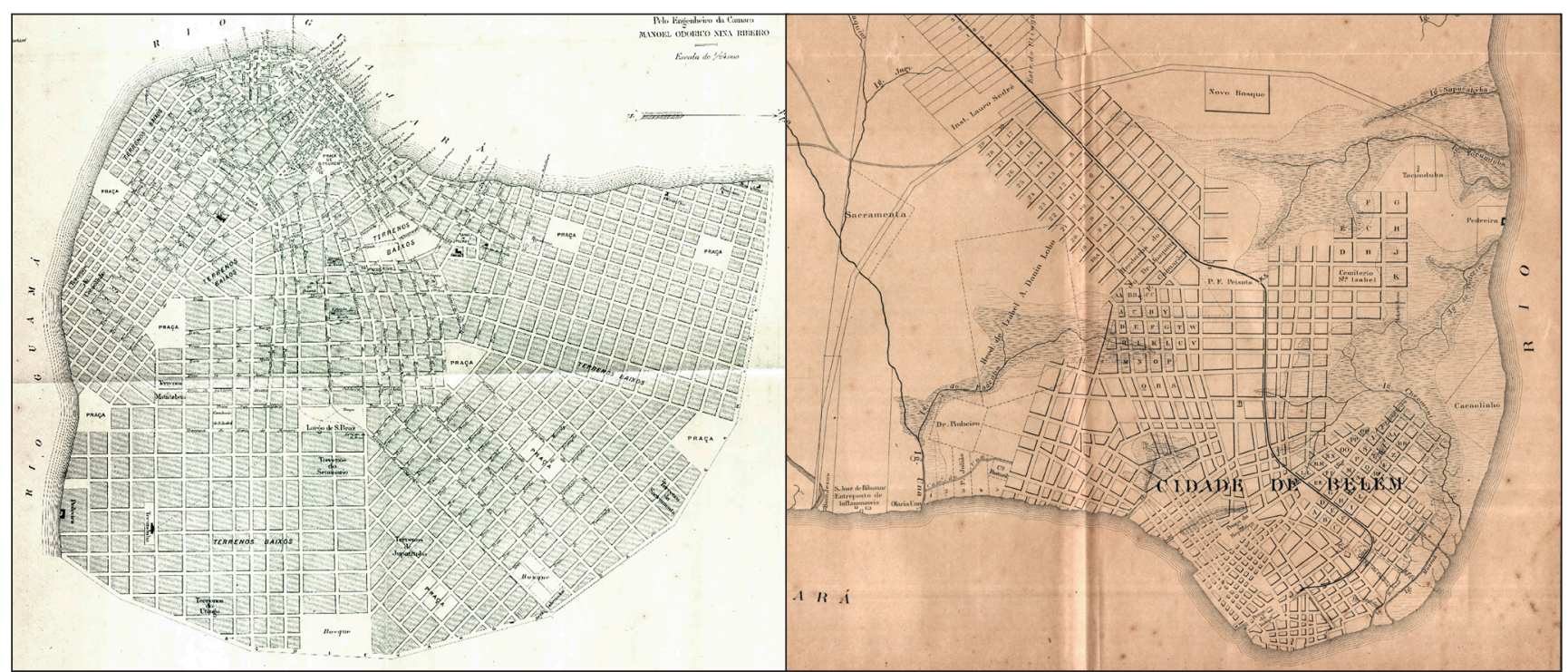

Figura 4 - À esquerda, o Plano de Expansão de Belém, de Nina Ribeiro (1 883-1 886), com referência às vias do entorno da Estrada de Bragança; à direita, a ocupação da cidade no início do século XX, com referência aos quarteirões loteados pelo Município. Fonte: João de Palma Muniz (1904).

Como mencionado anteriormente, a pesquisa nos termos de aforamento mostrou que as primeiras alienações de terra no entorno da Estrada de Bragança foram constituídas em 1869. Tal era a expressividade do número de concessões na área que foram aforados 222 terrenos em apenas 46 dias, evidenciando que a Câmara Municipal não só atendia àqueles que porventura solicitassem terreno na área, mas adotava uma iniciativa deliberada de arruamento e distribuição intensiva de terras no local. As notícias veiculadas nos periódicos da época confirmam a existência de um planejamento municipal para a concessão de terras no entorno da Estrada de Bragança: 
A vereação de 1869, de acordo com um plano e planta de arruamento de terrenos devolutos na estrada de Bragança, em que estava compreendido um bosque de 300 braças de frente e 150 de fundo, aforava esses terrenos observando todas as formalidades legas [sic]. ${ }^{109}$

Para melhor compreender a relação dessas concessões de terra com o planejamento da malha urbana retilínea, fechada e ortogonal estabelecida no entorno da estrada, foi necessário realizar a espacialização gráfica da localização e dimensões dos terrenos aforados, o que permitiu reconstituir o desenho dos primeiros lotes e inseri-los na malha viária. Isso foi possível por meio das informações detalhadas e precisas contidas nos documentos de aforamento (identificação do lote, terrenos confinantes, localização e número da quadra em que estava inserido), capazes de demonstrar que o aforamento desses lotes remetia a um planejamento urbanístico anterior ao ato de concessão:

se lavra o presente termo de aforamento, pelo qual o suplicante Antonio Franco Pinheiro se obriga a pagar anualmente a Camara Municial foro de2.275 braças quadradas de terreno equivalente a trinta e duas e meia braças de frente na estrada de Bragança, lado oriental com setenta de fundos, entestando pelo lado direito com o terreno concedido, digo, limitando pelo lado direito com a travessa Timbó e pelo esquerdo com José Joaquim Pimenta de Magalhãez no quarteirão trez segundo a planta existente no archivo. ${ }^{110}$

Apesar de a planta mencionada nesse trecho não ter sido localizada, encontrou-se nos arquivos da Codem o registro da "Planta de loteamento do bairro da Pedreira", que mostra o parcelamento desenvolvido nos eixos de expansão da cidade no século XIX, englobando os atuais bairros Fátima, Umarizal, Nazaré, São Brás, Marco e Pedreira (Figura 5). Essa planta, conhecida entre os funcionários da Codem como "Planta Índice", apresenta a identificação dos quarteirões e lotes do local e serve de subsídio para o levantamento da cadeia dominial dos terrenos em questão.

Provavelmente a Planta Índice é uma cópia do "plano de arruamento e bosque, que serviu de base às concessões d'esses aforamentos" 111 realizados no entorno da Estrada de Bragança. A divisão de lotes sugerida nessa planta é útil para entender como foi viabilizada a ocupação da área e como o parcelamento planejado foi apropriado e concretizado no local. A descrição da quadra, do lote e, principalmente, de seus confinantes nos termos de aforamento permite comparar a situação dos terrenos concedidos por aforamento com a representação da planta em questão, como se pode observar no Quadro 2:
109. Cf. Jornal do Pará (1873, p. 1, grifo nosso).

110. Belém (1869b, f. 59, grifos no original).

111. Cf. Jornal do Pará (1873, p. 1). 


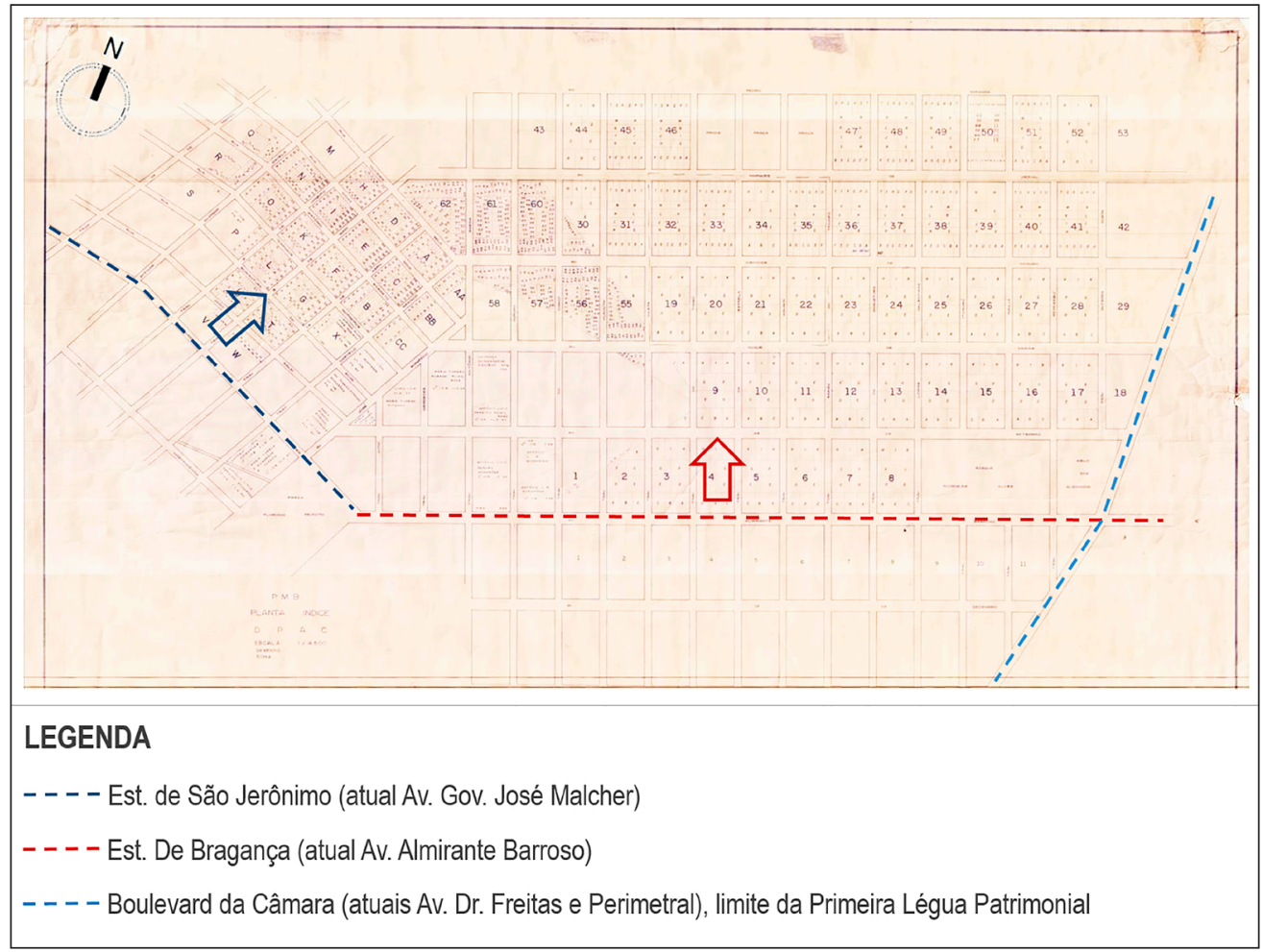

Figura 5 - Planta de loteamento do bairro da Pedreira ou Planta Índice. Apresenta a ocupação ao longo das antigas Estradas de São Jerônimo (em azul escuro) e de Bragança (em vermelho), que constituíam os eixos de expansão da cidade no século XIX. Fonte: Acervo da Companhia de Desenvolvimento e Administração da Área Metropolitana de Belém (adaptado).

Quadro 2 - Localização dos terrenos aforados de acordo com os termos de aforamento e com a Planta Índice

\begin{tabular}{|l|l|l|}
\hline $\begin{array}{l}\text { Localização dos terrenos aforados de } \\
\text { acordo com os termos de aforamento }\end{array}$ & $\begin{array}{c}\text { Planta de "Parcelamento do Bairro da } \\
\text { Pedreira" }\end{array}$ \\
\hline $\begin{array}{l}\text { "foro de } 2.275 \text { braças quadradas de } \\
\text { terreno equivalente a trinta e duas e meia } \\
\text { braças de frente na estrada Duque de Caxias } \\
\text { com setenta de fundos, entestando pelo } \\
\text { lado direito com o terreno concedido ao } \\
\text { Padre Filippe Sant'Anna [?] D. Vilhena e pelo } \\
\text { esquerdo com a travessa Lomas Valentinas } \\
\text { no quarteirão número quatorze segundo a } \\
\text { planta existente no archivo [...]". }\end{array}$ & & \\
\hline
\end{tabular}




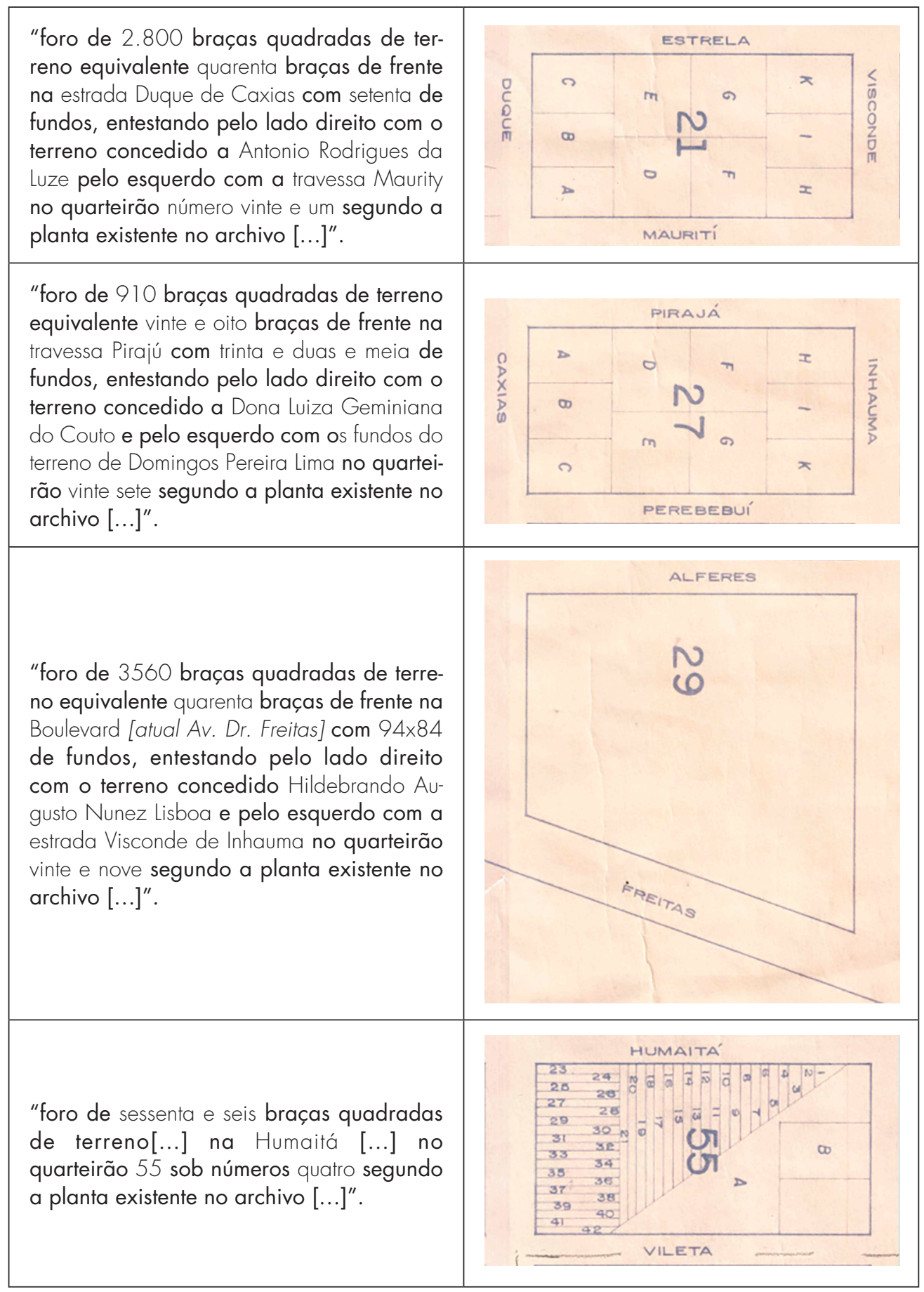

Fonte: Elaborado a partir dos termos de aforamento (Belém, 1869e, f. 30, 24, 71 e 132; 18731883b, f. 15) e da Planta de Parcelamento do Bairro da Pedreira. Acervo da Companhia de Desenvolvimento e Administração da Área Metropolitana de Belém.

Nota: Texto em negrito - trechos impressos. Texto sem negrito - trechos manuscritos. 
112. Essas dimensões excluem as áreas de calçada.

113. Cf. Albuquerque (1989); Penteado (1988).
Esse comparativo entre a localização e caracterização especificadas nos termos de aforamento e na Planta Índice, bem como as notícias veiculadas nos jornais da época sugerem que o desenho de lotes representado nessa planta guiou a concessão de terrenos no local e que o aforamento foi o instrumento utilizado para concretizar um plano de ocupação do patrimônio da Câmara no entorno da Estrada de Bragança, do qual a planta em questão é um registro aproximado.

Os quarteirões planejados para o local apresentam, no geral, uma forma regular e invariável que se estende por toda a área. Existem variações apenas nos limites do parcelamento, quando a forma das quadras passa a ser condicionada pelo eixo não ortogonal das vias adjacentes. As quadras padrão são retangulares e extensas, com 143 metros de frente e 308 metros de fundo, ${ }^{112}$ aproximadamente - dobro das dimensões das quadras do parcelamento adjacente, estruturado a partir da Estrada de São Jerônimo.

Ainda que o desenho das quadras seja uniforme, a planta estudada mostra diversas tipologias de lotes, que variam conforme sua localização na área. Fica evidente a tentativa de estabelecer uma hierarquia na ocupação, com lotes maiores próximos à Estrada de Bragança - cumeada do sítio e principal eixo de ligação da cidade com o interior do estado - e lotes menores localizados perto de áreas alagáveis. Essa diversidade tipológica é uma expressão formal de uma estratégia de ocupação do local diversificada e abrangente, que abre oportunidade para apropriação por diferentes camadas sociais, uma vez que o valor dos foros a ser pago pelo enfiteuta era proporcional à área do terreno que recebia.

A reconstituição gráfica dos lotes aforados mostra que, principalmente no eixo da Estrada de Bragança, a forma desses terrenos diverge da representação da Planta Índice. Nesse local, a área dos terrenos aforados chegava a ser cinco vezes maior do que o previsto na planta, revelando outro padrão morfológico que intensifica a hierarquia tipológica implantada.

A área, testada e profundidade dos lotes implantados na porção mais próxima à Estrada de Bragança, suplanta as dimensões usuais no núcleo de ocupação tradicional da cidade, conferindo a esse parcelamento uma feição de transição entre o urbano e o rural. Com o início da ocupação da área, foram construídas ao longo da Estrada de Bragança diversas residências que funcionavam como casa de campo daqueles que habitavam o núcleo inicial da cidade. ${ }^{113}$ Essas residências, conhecidas localmente como "rocinhas", dividiam o amplo espaço do lote com pomares e hortas, evidenciando o caráter periurbano dos primeiros anos da ocupação da área. 


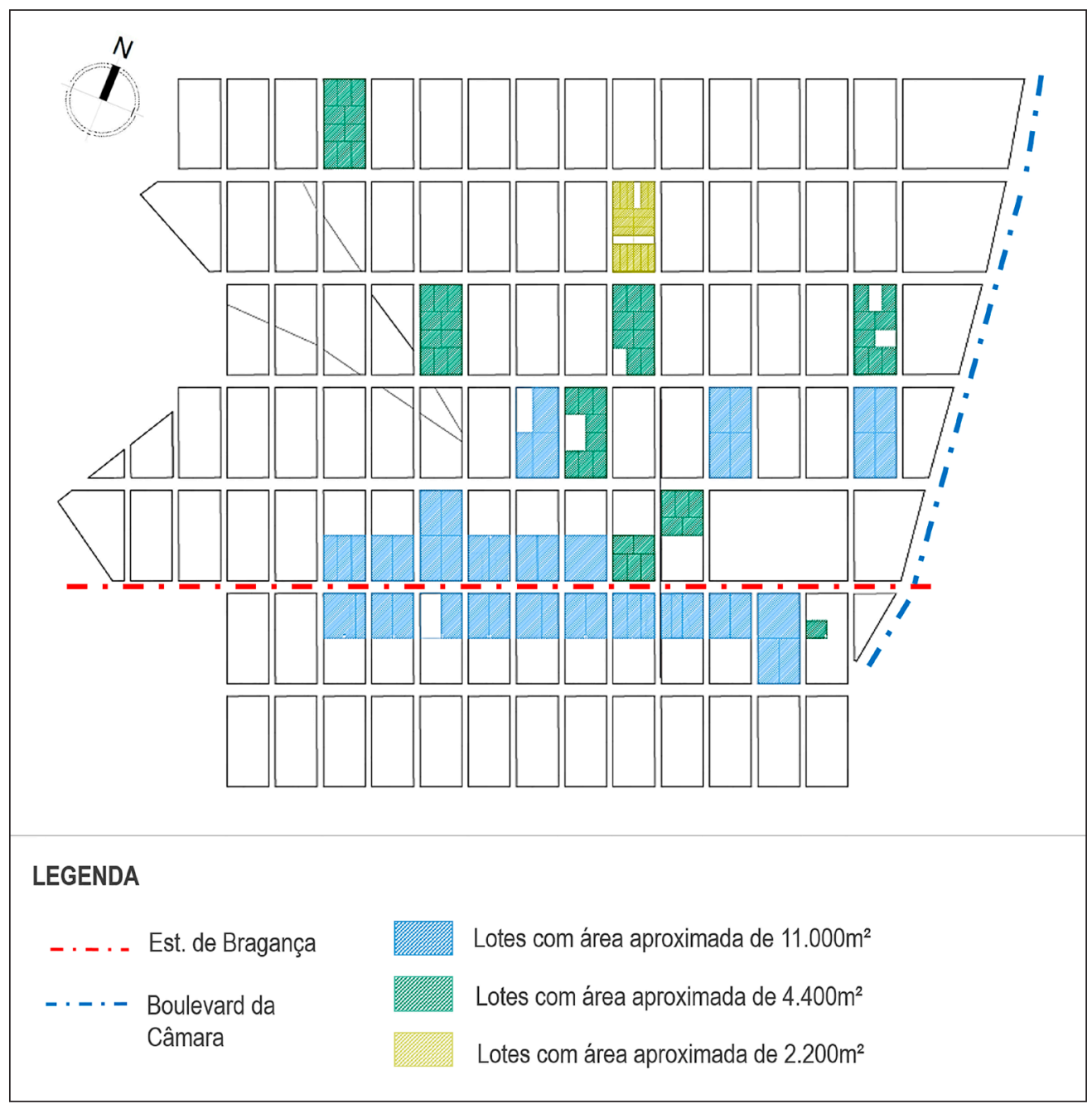

Figura 6 - Espacialização gráfica dos aforamentos no entorno da Estrada de Bragança. Lotes maiores (em azul), localizados na parte mais próxima à estrada e com dimensões diferentes do padrão apresentado na Planta Índice. À medida que se distanciam da estrada, o tamanho dos lotes tende a diminuir. Fonte: Elaborado pelos autores a partir da base cadastral do município de Belém (CODEM, 2000) e dos Termos de Aforamento da Câmara Municipal (Belém, 1869, 1869-1870, 1870-1873, 1873-1883).

Diferentemente dos grandes lotes e da hierarquia morfológica existente no entorno da Estrada de Bragança, o loteamento implantado a partir da Estrada de São Jerônimo, apresenta lotes estreitos e uma ocupação consideravelmente mais adensada. Isto porque a posição políitica dos diferentes grupos que estiveram à frente da Câmara Municipal foi preponderante para nortear as características morfológicas e socioespaciais dos loteamentos municipais. As ideias divergentes ficavam evidentes nos textos dos jornais que circulavam na cidade, os quais frequentemente retratavam críticas mútuas e tentativas de depreciar o trabalho realizado pelo grupo rival: 
114. Cf. O Liberal do Pará (1870, p. 2, grifo nosso)
A Camara liberal prestou tantos, e tão relevantes serviçoes que enumeral-os seria longo; entretanto para que o s. exc. o sr. dr. João Alfredo, que não conhece os homens do Pará, possa ficar fazendo idéa da injustiça com que tem sido tratados os membros do partido liberal, especialmente do sr. dr. Malcher, para que o publico possa fazer o seu juízo que, necessariamente, será a favor d'aquelles que dirigião a nossa Camara durante dezesseis anos, apresentaremos as seguintes considerações:

Se a Camara Municipal, que teve por presidente o nosso amigo o sr. dr. Malcher, não fez serviços, que nome se dará aos trabalhos das aberturas das ruas dos Tamoyos, Pariquis, Caripunas, Timbyras, da Conceição de S. Miguel e S. Silveste?

Quem não sabe que as travessas de S. Matheus, Apinagés, Tubinambás e Jurunas são obras da Camara, presididas pelo sr. dr. Malcher?

Quem não sabe que no quarto districto a praça de D. Izabel, travessa Souza Franco, D. Januaria, D. Romualdo de S. Coelho, D. Romualdo Antonio de Seixas e Pedro $1^{\circ}$ são mudos, mas eloquentes testemunhos dos serviços prestados pela Camara Municipal, cujos membros são tão indignamente tratados, por aquelles que nada fizeram em beneficio ao município?

Quem não sabe que parte da estrada de $\mathrm{S}$. Jeronimo, (desde a travessa 2 de dezembro até a praça da Independencia) e que as travessas João balbi, Boaventura da Silva, Domingos Marreiros, Antonio Barreto, Diogo Moia, Oliveira Belo e Bernal do Couto são obras feitas pela Camara, presidida por aquelle que se quer a todo custo desconceituar?

Se lançarmos á vista para as travessas perpendiculares á estrada da Independencia, veremos 14 de Março, 25 de Março, 9 de Janeiro, 3 de Maio, 14 de Abril, Caldeira Castello branco e José Bonifácio de Andrade atestarem o zelo da câmara cujo presidente era o nosso amigo dr. José da Gama Malcher.

A estrada da Independencia e a Praça do mesmo nome, cujo tamanho e beleza só a cegueira poderá contestar, são serviços da Camara composta de liberaes!

A estrada que vae da dita praça ao marco do boulevard no perímetro da légua patrimonial é ainda serviço de liberaes.

Releva notar que todas estas estradas, ruas e travessas em 1852 eram matto, e somente matto! [...]

Quem poderá desconhecer os serviços da Camara Municipal esses dezesseis annos?[...]

Só o sr. Conego Siqueira ou algum conservador desleal, é que ousará a tanto! ${ }^{114}$

Como atesta o texto em favor da câmara liberal, transcrito a seguir, o arruamento de áreas alagadas (perto do atual canal da Travessa Três de Maio) e a divisão da terra em lotes menores eram estratégias dessa Câmara para viabilizar o aterramento da área e facilitar a concessão de terrenos à população mais pobre: 
Veja-se os subúrbios de S. João e Marizal transformados em uma nova cidade, e diga-se que esse trabalho utilíssimo não absorveu algumas sommas dos retidos do município.

E nem, para desvirtuar o acto da a-cmara [sic], se diga que não havia imperiosa necessidade de abrirem-se essas ruas; porque é somente por ellas que se podia chegar aos pântanos que cercão a cidade para então procurar dissecal-os; é com sua abertura que se conseguio maior ventilação para o centro da cidade; é com a multiplicação d'essas ruas e praças que se proporcionou á população menos favorecida da fortuna, meios de obter habitações a baixo preço [...].

Se a Constituição se admira do numero das concessões, deve refletir que há muito mais conveniência para o município nas distsibuição [sic] dos seos terrenos pelo maior numero possivel de habitantes; do que entregal-os todos a meia dúzia de felizes como succedeo com a camara intrusa do sr. Siqueira; porque quanto mais dividida a propriedade menor numero de indigentes existirá, alem de que os cidadãos menos abastados, ou mesmo pobres, poderão edificar nos terrenos a elles aforados. ${ }^{115}$

Assim, tanto a Planta Índice da ocupação quanto os depoimentos de partidários da Câmara Municipal revelam que o parcelamento efetuado pela Câmara de perfil liberal a partir da Estrada de São Jerônimo é caracterizado pela divisão intensa da terra, visando maior democratização na partilha fundiária, ao passo que o parcelamento encabeçado pela Câmara de perfil conservador a partir da Estrada de Bragança apresenta, em grande parte, vastos terrenos e, consequentemente, maior concentração de terra nas mãos dos foreiros.

Importa então compreender que, em um contexto no qual os oficiais da Câmara eram responsáveis pela administração das terras, a ação do poder local sobre a cidade era direcionada pela orientação política e pelos interesses dos integrantes da Câmara Municipal. Ribeiro, em seu estudo sobre a concessão de terras em São Paulo durante o período colonial, demonstra que cerca de $70 \%$ dos beneficiários das concessões possuíam vínculo direto ou indireto com alguém que ocupava cargo na Câmara da cidade. ${ }^{116}$ Esses casos expressam a importância de relacionar o processo de estruturação fundiária e a morfologia urbana com as demandas políticas e os interesses das elites locais na compreensão do espaço urbano.

As dimensões e a morfologia dos terrenos originados do parcelamento realizado pela Câmara conservadora permitiram e induziram a criação de uma reserva fundiária para seus foreiros. Estes, diante do adensamento populacional ocorrido no século XX, ${ }^{117}$ se utilizaram do direito de traspassar suas terras, por meio do desmembramento dos lotes originais em lotes menores, e absorveram a renda fundiária proveniente da valorização do solo (Figura 7).
115. Cf. O Liberal do Pará (1874, p. 1, grifo original).

116. Ribeiro (2017).

117. Cf. Penteado (1988). 
118. Cf. Glezer (2007a).

119. Fridman (1999).

120. Ferreira (1976, p. 18 apud Fridman, 1999, p. 256).

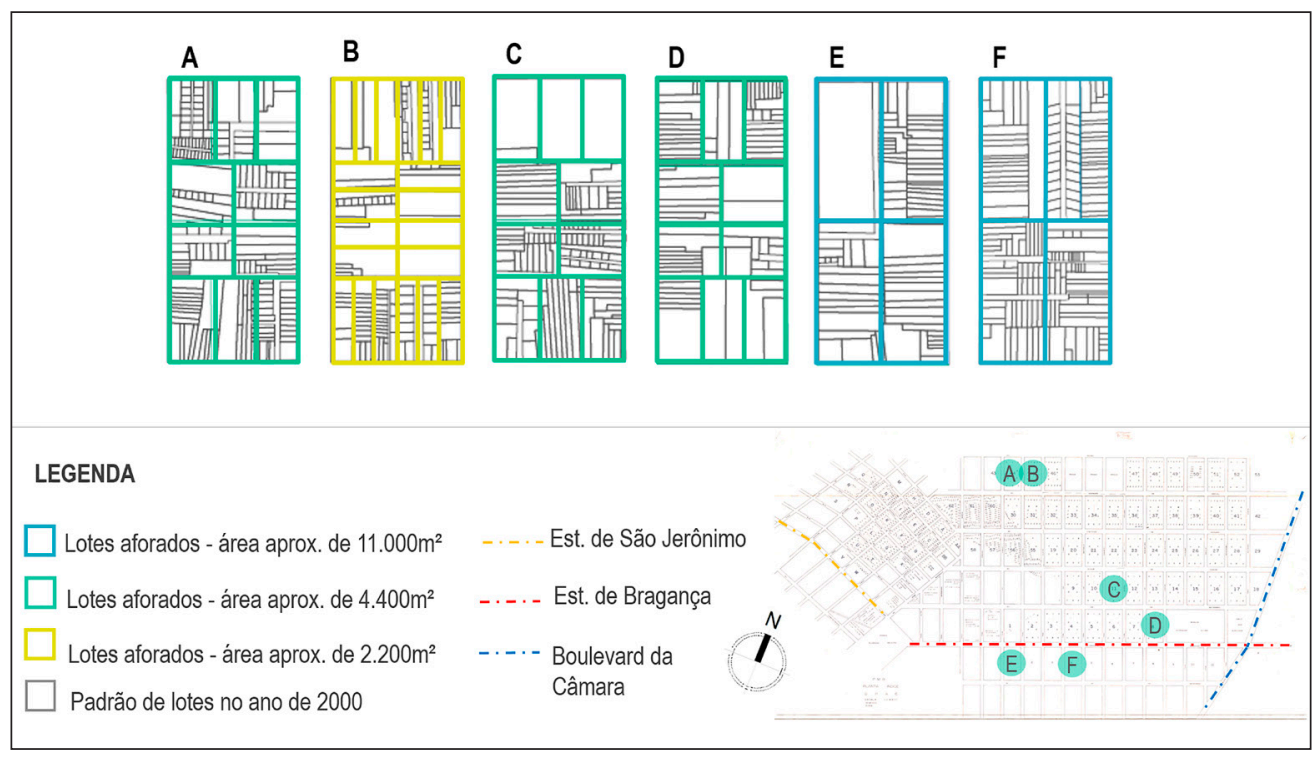

Figura 7 - Transformações nas formas dos lotes aforados pela Câmara Municipal demonstram o adensamento do solo ao longo do século XX por meio do desmembramento dos terrenos. Fonte: Elaborado pelos autores a partir da base cadastral do município de Belém (CODEM, 2000) e dos Termos de Aforamento da Câmara Municipal (Belém, 1869, 1869-1870, 1895-1912, 1913-1931).

Além das áreas que o Município aforava, outras ocupações eram feitas sem a requisição de terrenos à Câmara, de modo que o ocupante detinha apenas a posse da terra não legalizada. Essa prática foi determinante para a formação de grandes áreas de posse na cidade que, ocupadas inicialmente de forma precária, posteriormente foram oficializadas pela ratificação municipal.

Esse processo de apropriação informal das terras do patrimônio municipal era comum em diversas cidades e revelava a dificuldade das Câmaras em acompanhar a ocupação de tão vastas áreas sob seu domínio. ${ }^{18}$ Fania Fridman relata, por exemplo, que o patrimônio da Câmara do Rio de Janeiro sofreu com o processo de grilagem desde os primeiros séculos de ocupação. ${ }^{119}$ Em meados do século XVII, a Câmara carioca solicitou à Corte o tombamento de seu patrimônio por considerar que "todos os bens do Conselho, terras e datas da dita Câmara" haviam sido "usurpados por pessoas poderosas". ${ }^{120}$

Em Belém, o Município passou a legalizar muitas dessas ocupações por meio do procedimento conhecido como "ratificação de posse", que outorgava legalmente ao posseiro o domínio útil do terreno, permanecendo o domínio direto da terra com o Município. Acredita-se que as iniciativas de legitimar posses dentro do patrimônio da Câmara não são consequências diretas da aplicação da Lei de Terras, pois essa lei não incidia sobre as sesmarias municipais. Mas, de alguma 
forma, a ideia de regularização fundiária e formalização das ocupações precárias, trazida por essa legislação, reverberou em políticas estaduais ${ }^{121}$ e ações municipais de regularização da ocupação de seu patrimônio - que, por um lado, honravam o uso e a ocupação da terra e, por outro, balizavam o parcelamento do solo por parte do poder público.

Assim, ainda que excluísse de suas disposições as áreas urbanas e sesmarias confirmadas, como era o caso da Primeira Légua Patrimonial de Belém, a lei reconhecia a posição do ocupante como responsável pela cultura e ocupação efetiva. Esse reconhecimento é especialmente significativo em um contexto no qual o cultivo e a ocupação, apesar de serem requisitos das concessões formais de terra, muitas vezes não eram efetuados.

É importante ressaltar que, na prática, os posseiros muitas vezes dominavam, por seu poder e posição social, uma área maior que aquela que de fato era espacialmente ocupada por meio de habitação ou lavoura. Muitas posses foram ratificadas com base nesse domínio exercido pelos posseiros, resultando na formação de grandes áreas particulares onde a ocupação espacial ainda era rarefeita. Como consequência, a configuração urbano-fundiária da cidade apresenta grandes extensões de terra - originadas de posses ratificadas a partir da segunda metade do século XIX ou mesmo de aforamentos constituídos desde os primeiros séculos de ocupação - concentradas nas mãos de algumas famílias, como Acatauassú Nunes, Ferro Costa, Lameira Bittencourt, Lobato, entre outras. ${ }^{122}$ Como estas eram grandes áreas cujo domínio útil havia sido concedido pelo Município ao particular, o padrão de lotes nelas implantado pouco se sujeitou à interferência da administração. Observase então que, ao aforar ou ratificar terrenos a particulares, o Município lhes outorga a possibilidade de, em maior ou menor escala, transformar morfologicamente a cidade por meio do parcelamento do solo, como será discutido a seguir.

\section{TRANSFORMAÇÕES MORFOLÓGICAS E OS LIMITES DA ATUAÇÃO MUNICIPAL NA ESTRUTURAÇÃO URBANA}

A morfologia urbana da Primeira Légua Patrimonial foi em grande parte estruturada pelas iniciativas de loteamento do patrimônio municipal empreendidas pela própria Câmara. A concessão da segunda légua de terras à cidade de Belém, entretanto, foi realizada quase três séculos após a primeira concessão, de modo que parte significativa dos terrenos já havia sido alienada a particulares. ${ }^{123} \mathrm{Uma}$ vez que a área se enquadrava nas disposições da Lei de Terras, esses particulares
121. Cf. Oliveira; Fischer (2017); Pará (1891).

122. Cf. Mourão (1987).

123. Cf. Corrêa [19--]; Muniz (1904). 
124. Cf. Conzen (2001); Moudon (1997). detinham o domínio pleno da propriedade e não estavam sujeitos a qualquer senhorio. Logo, a área incorporada ao patrimônio do Município era constituída apenas pelas terras devolutas que se achavam dentro da nova légua.

O tecido urbano de Belém revela em sua morfologia o resultado das ações municipais de estruturação urbana e das diferentes políiticas fundiárias que marcaram as concessões de terra ao Município. Como consequência das iniciativas de arruamento e parcelamento do solo dentro da Primeira légua Patrimonial, constituiu-se uma trama viária consideravelmente mais integrada e articulada. Na área da segunda concessão, a presença de grandes terrenos particulares /alienados antes da doação da légua) contribuiu para a formação de uma malha viária desconectada, onde os loteamentos ficaram contidos nas propriedades públicas ou particulares (Figura 8). Desse modo, os limites público-privado aparecem claramente como limites morfológicos, reforçando o que mostram tradicionais estudos da área de morfologia urbana. ${ }^{124}$

Contudo, mesmo dentro dos patrimônios municipais, o papel do poder local na estruturação urbana e sua ałuação enquanto senhorio das terras municipais são limitados pelo próprio regime enfitêutico, que confere ao foreiro autonomia suficiente para interferir na forma e no status fundiário do lote. Com isso, existe também uma potencial tensão entre senhorio e enfiteuta a respeito do controle da terra, que se intensifica com a consolidação da ideia de propriedade privada absoluta.

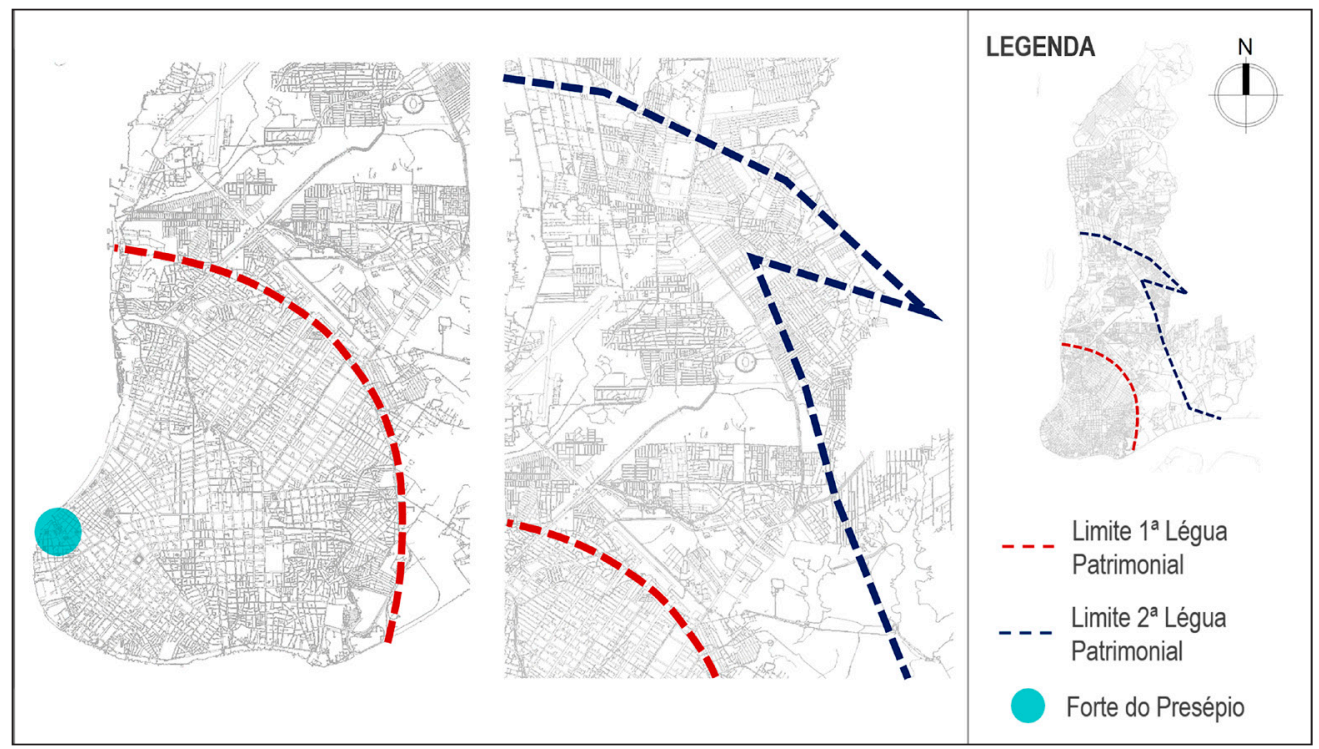

Figura 8 - Malha viária da cidade de Belém e sua relação com os limites das terras recebidas pelo Município. Na Primeira Légua Patrimonial, onde o Município tinha hegemonia fundiária, o tecido urbano é mais articulado e coeso. Fonte: Elaborado pelos autores a partir da base cadastral do município de Belém (CODEM, 2000). 
Diante do contexto de privatização das terras rurais e afirmação do ideário de propriedade moderna absoluta no século XIX, tornaram-se cada vez mais frequentes, tanto nas áreas rurais quanto nas urbanas, o desaparecimento do contrato enfitêutico e a integração da propriedade plena nas mãos do senhorio ou do enfiteuta. Esse processo de extinção do domínio relativo, conhecido como desincorporação, ${ }^{125}$ acontece também nas terras públicas, quando o domínio direto das terras municipais aforadas passa a ser vendido (normalmente para os próprios enfiteutas que as ocupavam) de modo a integralizar a propriedade plena da terra nas mãos do particular. ${ }^{126}$ Como consequência, em muitas cidades os patrimônios municipais vão sendo drasticamente reduzidos ou mesmo extintos.

Além disso, nas primeiras décadas do século XX o Código Civil ${ }^{127}$ introduziu o direito de resgate das enfiteuses constituídas há mais de trinta anos, favorecendo o enfiteuta com o direito de tornar-se proprietário pleno da terra que ocupava. Dessa forma, o regime enfitêutico vai perdendo força ao longo do tempo e permite que o regime de propriedade privada se estabeleça dentro dos até então patrimônios municipais e religiosos. Assim, a partir da Lei de Terras de 1850, o sistema de aforamentos vai sendo progressivamente enfraquecido: inicia-se um processo voluntário de desincorporação das terras aforadas em prol da instituição da propriedade plena e livre; garante-se ao enfiteuta o direito de tornar-se proprietário pleno da terra por meio do resgate (Código Civil de 1916); e, por fim, proíbe-se a constituição de novas enfiteuses (Código Civil de 2002), permanecendo as ainda existentes sob o regimento do primeiro Código Civil.

Em alguns casos, como o da Primeira Légua Patrimonial de Belém, os aforamentos já constituídos persistem e poucos resgates são realizados, mantendose a bipartição da propriedade dos terrenos. Isto porque a Codem, empresa de economia mista que passa a administrar o patrimônio municipal a partir da década de 1970, resistia em proceder ao resgate das enfiteuses, retendo o domínio direto dos terrenos. Foi somente a partir da década de 2000, com a vigência do novo Código Civil, que a Codem passou a conceder sem oposição os resgates solicitados pelos enfiteutas, dando início ao processo de desincorporação do patrimônio municipal.

Entretanto, ainda que grande parte das enfiteuses constituídas continuasse existindo, a concepção de domínio da terra relativizado, inerente ao regime enfitêutico, vai se enfraquecendo em prol da consolidação da noção de propriedade privada, reforçando a já existente autonomia jurídica do enfiteuta sobre a terra (intrínseca ao instituto da enfiteuse, que permite ao foreiro alienar voluntariamente o terreno, desde que o senhorio seja comunicado). Observa-se, então, que o enfiteuta possui o direito de interferir nos limites legais da parcela
125. Cf. Marx (1999). 126. Cf. Nascimento (2013). 127. Cf. Brasil (2003). 
128. Cf. Ersland (2010).

129. Cf. Ersland (2010).

130. Belém (1884-1885, f. 130). de terra, desfrutando de significativa autonomia legal. Portanto, a posição jurídica do detentor do domínio útil do lote e a autonomia que the é conferida são aspectos relevantes na estruturação da morfologia urbana e dos padrões de parcelamento.

Estudos morfológicos mostraram que na cidade de Bergen, Norvega, a forma dos lotes pouco foi alterada entre os séculos XVII e XIX, quando os terrenos eram apropriados por meio de aluguel anual, ${ }^{128} \mathrm{em}$ um sistema equivalente à enfiteuse. Geir Ersland defende que foi justamente a forte posição legal do detentor do domínio útil em relação ao detentor do domínio direto que permitiu tal fato, pois as mudanças nos padrões dos lotes começam a ocorrer na cidade a partir de quando a posição do primeiro é enfraquecida em prol do segundo, ou quando a distinção entre domínio útil e domínio direto é atenuada, tornando o interesse do ocupante mais vulnerável. ${ }^{129}$ Assim, o poder conferido ao foreiro do lote permitia-the defender seus interesses, que, no caso da cidade de Bergen, consistiam em manter o domínio de seu pedaço de terra.

No Brasil, por conta da tradição de origem portuguesa, a distinção entre os dois tipos de domínio resulta no fortalecimento da posição do enfiteuta, detentor do domínio útil, em virtude da importância conferida na tradição portuguesa ao uso e à ocupação da terra em detrimento do seu status legal.

Além disso, em um contexto distinto de ocupação das vastas terras brasileiras, o interesse do enfiteuta não era necessariamente manter o domínio sobre todo seu lote. Desse modo, a autonomia conferida ao detentor do domínio útil levou, em Belém, a uma alteração da tipologia do lote por meio do remembramento ou, mais frequentemente, do desmembramento desses terrenos. A alteração por desmembramento acontece principalmente quando o tamanho dos lotes ultrapassa as dimensões médias dos terrenos urbanos, abrindo a possibilidade de intensificar a ocupação do solo e gerar renda fundiária, tanto para o enfiteuta, por meio da venda do domínio útil (traspasse), quanto para o senhorio, por meio da porcentagem que the cabia sobre o valor dessa transação (o laudêmio).

A análise das transformações morfológicas nos lotes aforados pelo Município no século XIX mostrou que houve alteração na morfologia de alguns lotes implantados, ainda nos primeiros anos de ocupação. Na Figura 9 pode-se observar que antes do alinhamento e da demarcação do terreno aforado a Antônio Francisco Pinheiro, em 1869, já havia ocorrido um processo de desmembramento, com o traspasse de parte do terreno a Luiz Eduardo de Carvalho. ${ }^{130}$ Após o alinhamento outros desmembramentos ocorreram, e a morfologia do lote aforado pela Câmara continuou sendo alterada para o adensamento da ocupação. 


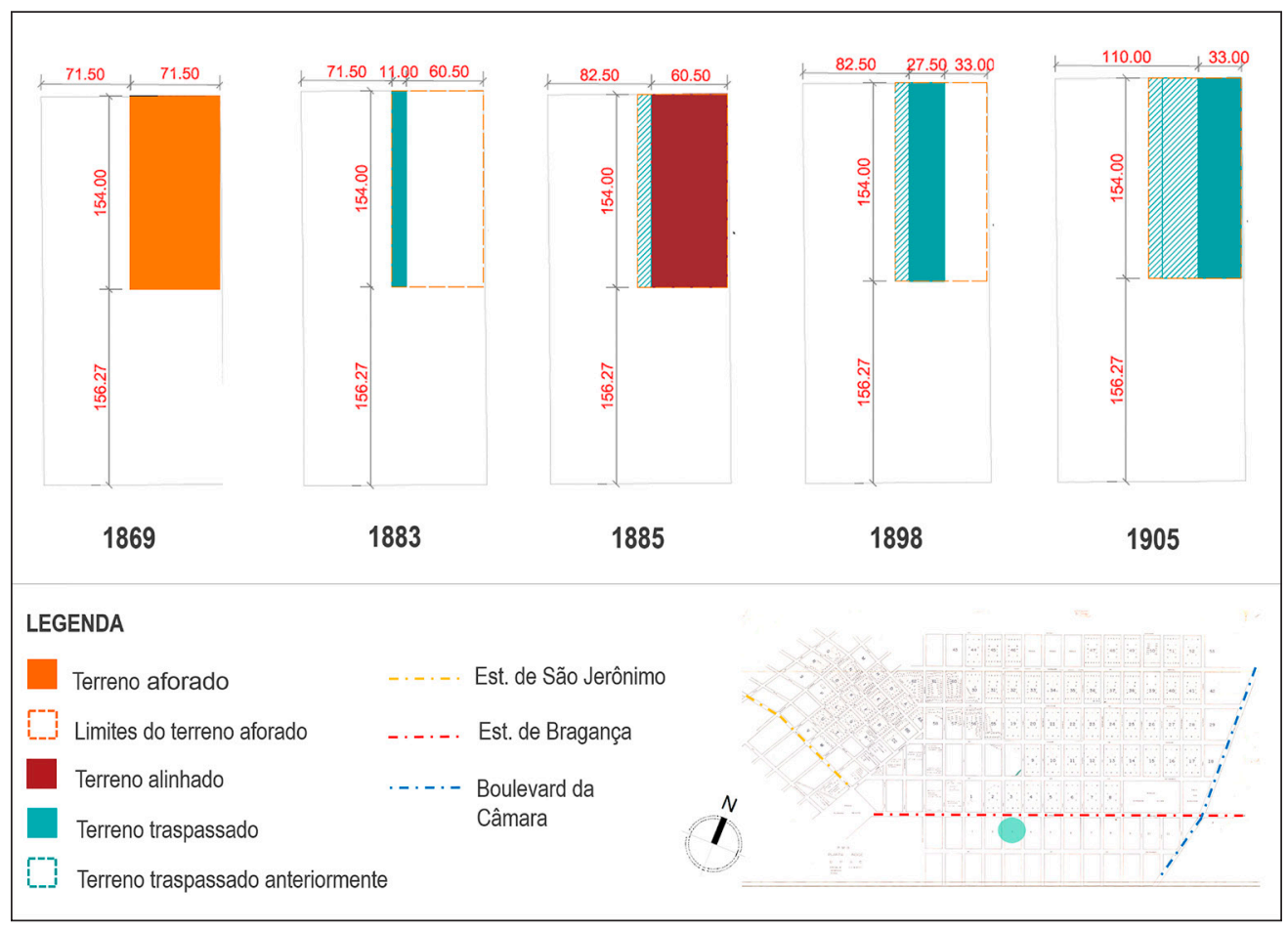

131. Cf. Mourão (1987).

Figura 9 - Transformações fundiárias e morfológicas no lote aforado pela Câmara Municipal em 1869 começam a ocorrer antes mesmo do alinhamento e da demarcação do terreno. Fonte: Elaborado pelos autores a partir dos termos de aforamento (Belém, 1869b, f. 59) e dos termos de alinhamento e arrumação da Câmara (Belém, 1884-1885, f. 130).

Dessa forma, a ałuação do Município na conformação morfológica da cidade é preponderante, mas a partir do momento em que o domínio útil da terra é outorgado ao particular - seja pelo aforamento, seja pela ratificação de posse - o poder para reconfigurar o padrão de lotes passa a pertencer ao enfiteuta. Isso acontece devido à própria característica do sistema enfitêutico, que garante ao detentor do domínio útil a possibilidade de dispor da terra através do traspasse, limitando de certa forma a continuidade da orientação morfológica pelo Município.

No caso das grandes áreas concedidas ou ratificadas pela Câmara, a ação do particular foi ainda mais contundente na definição do tecido urbano, estruturando até a malha viária e o macroparcelamento do solo, além do padrão de lotes. Em meados do século XX, quando a ocupação efetiva dessas áreas aconteceria, ela seria direcionada preponderantemente pelo detentor do domínio útil, por meio da implantação de arruamento e loteamentos particulares - ou, em muitos casos, pela própria população, que passaria a se apropriar dessas terras sem a devida titularidade fundiárial ${ }^{131}$ e as ocuparia à margem da regulação urbanística. 
132. Cf. Leonelli (2010). Cabe destacar que, em Belém, a primeira lei municipal de parcelamento do solo, designada como Lei Complementar de Controle Urbanístico (LCCU), foi instituída apenas em 1999. Entre as disposições dessa legislação destaca-se a definição de modelos e índices de ocupação do solo específicos para as diferentes zonas da cidade.
Portanto, devido à semelhança entre a autonomia do enfiteuta e a do proprietário absoluto, quando se consolida a noção de propriedade privada e surge um mercado de terras tal autonomia permite que o foreiro direcione as posteriores transformações jurídico-morfológicas da terra aforada. Esse papel de agente modelador do espaço ganha maiores proporções conforme o tamanho da área sob domínio do enfiteuta, podendo ele, dessa forma, interferir de maneira ainda mais significativa na morfologia da cidade. Assim, uma vez que a Câmara afora a terra, transfere ao foreiro a possibilidade de direcionar a morfologia do terreno a partir de então, devendo respeitar, entretanto, as limitações urbanísticas que vão ganhando corpo ao longo dos séculos.

É importante ressaltar que as legislações sobre o parcelamento do solo, munindo - Município de medidas reguladoras, surgem apenas em meados do século XX. A primeira lei de amplitude federal foi o decreto-lei n n $^{\circ}$, de 10 de dezembro de 1937 (regulamentado pelo decreto-tei no 3.079, de 15 de setembro de 1938), que visava principalmente regular as questões referentes à transferência de lotes e garantir o direito dos compradores. No que diz respeito às regulações urbanísticas, o decreto instituiu a exigência de que o empreendedor apresentasse um plano de loteamento, a planta da gleba, a caracterização do seu entorno, a definição das áreas dos lotes com sua respectiva numeração e o dimensionamento das vias e espaços livres. Esses elementos precisariam também ser submetidos à Prefeitura, que deveria aprovar o plano de loteamento. Por outro lado, essa legislação não dispunha sobre os aspectos urbanísticos desejáveis para o projeto de parcelamento do solo, relegando tal regulação aos Municípios, que também permaneceram por muito tempo silenciosos a esse respeito. ${ }^{132}$

A fim de contemplar aspectos urbanísticos não considerados pelo decretolei, em 19 de dezembro de 1979 foi baixada a lei n 6.766, que distinguia os papéis do Município e do particular no parcelamento do solo urbano e considerava, por exemplo, aspectos de inserção urbana, infraestrutura e dimensionamento mínimo. A partir de então, cabe ao Município fornecer diretrizes para o desenho da área a ser parcelada, garantindo alguns requisitos mínimos. Por outro lado, a decisão projetual do desenho urbano, a escolha por se fazer desta ou daquela maneira, cabe ao proprietário da gleba.

As leis de parcelamento do solo reforçam a ideia de que o loteamento é objeto de interesse direto tanto do proprietário como da Municipalidade. Entretanto, nota-se que a prática de desenhar a cidade fica, nesses casos, a cargo dos entes privados, cujos direitos de propriedade lhes possibilitam interferir na forma da cidade. Assim, a figura do proprietário privado que surge no Brasil na segunda metade do século XIX culmina com a figura do loteador, agente provedor de terra urbanizada e responsável, em muitos casos, pela expansão urbana. 
Por outro lado, houve casos em que a Prefeitura de Belém reouve o domínio de grandes áreas concedidas a particulares, por meio de desapropriação /do domínio útil, na Primeira Légua Patrimonial, ou do domínio pleno, nas demais áreas da cidadel para implementar ações de melhoria e reordenamento urbanístico, modificando o arruamento e o parcelamento do solo. ${ }^{133}$ Dessa forma o Município, por meio dos direitos constitucionais que the são atribuídos, retoma a possibilidade de interferir no desenho urbano e na estrutura fundiária da cidade, a partir da ótica da predominância do interesse público sobre o interesse privado.

\section{CONSIDERAÇÕES FINAIS}

Durante o período de vigência do regime sesmarial, até 1822, era comum que cada nova vila fundada recebesse da Coroa Portuguesa uma sesmaria para formar o patrimônio do Concelho, a partir da qual poderia conceder terrenos por meio do instituto jurídico do aforamento. A cidade de Belém recebeu sua sesmaria poucos anos após a fundação da Vila, de modo que a maior parte da ocupação da cidade foi realizada depois de formado o patrimônio municipal. Dessa forma, a Câmara foi responsável por gerir a ocupação que se processava em seu patrimônio, por meio da concessão de aforamentos e da ratificação de posses.

$\bigcirc$ conceito moderno de propriedade privada e o reconhecimento de seu valor de mercado, trazidos pela Lei de Terras de 1850, impactaram o trato da Câmara para com os lotes urbanos, ainda que esse não fosse o escopo da lei. Tal influência se deu tanto na estrutura fundiária da cidade, quanto em sua morfologia, com a proliferação das ações de alinhamento e de parcelamento do solo efetuadas pelo Município.

Para Murillo Marx, ${ }^{134}$ a desincorporação do domínio relativo sobre a terra (de dois senhorios) e a emergência de um senhorio absoluto, individual, com plenos direitos sobre sua propriedade (inclusive de mantê-la intacta ou retê-la), agravaram a característica de finitude da terra. Essa questão intensificaria a situação da terra como mercadoria e estimularia sua troca. Nessa linha de raciocínio, a situação de proprietário e a desvinculação do domínio do poder público (Coroa ou Município) conferiam certa liberdade ao transmitente e ao adquirente, que poderiam negociar sem qualquer restrição ou intervenção do poder público.

$\bigcirc$ caso da Primeira Légua Patrimonial da cidade de Belém, entretanto, é peculiar. De um lado, observa-se que as disposições da Lei de Terras e o surgimento do conceito de propriedade privada reverberaram na forma de apropriação da
133. Cf. Cadastro Municipal (2000).

134. Marx (1999). 
terra urbana, onde o loteamento, caracterizado pelo parcelamento sistemático da terra em lotes para comercialização, foi viabilizado pelo próprio Poder Público ainda em meados do século XIX. $\bigcirc$ caso de Belém mostra, então, que essas transformações na forma de apropriação da terra e nas relações fundiárias ocorreram dentro do sistema enfitêutico, com a permanência do domínio direto do Município sobre a Primeira Légua Patrimonial.

A noção de proprietário como dono único e absoluto da terra teria resultado de uma mudança no conceito de propriedade, por sua vez oriunda das transformações socioeconômicas engendradas pela Revolução Francesa, do liberalismo inglês e da lógica de produção capitalista, baseada na propriedade privada exclusiva. Entretanto, mais do que a existência de um proprietário absoluto desatrelado do senhorio, essas mudanças parecem ter afetado o conceito de propriedade como um todo, de forma que o foreiro (sempre contemplado com poderes de uso, gozo e disposição do bem), embora permaneça atrelado ao domínio direto do Município, exerce sobre a terra os mesmos direitos que cabiam ao proprietário, cuja figura adquire um caráter absoluto. Ou seja, acredita-se que não é a ruptura do domínio relativo e o estabelecimento do domínio absoluto em si, mas a transformação do conceito de propriedade, desenvolvido no Brasil a partir da Lei de Terras (com a distinção enfática entre patrimônio público e privado), que, enfatizando seu caráter de propriedade privada e fortalecendo a autonomia do particular, estimula a disponibilização da terra como mercadoria.

Como na enfiteuse, os direitos do concessionário são muito similares aos do proprietário, o fato de não obter a propriedade plena da terra não o impediria de destiná-la a quem e como quisesse, devendo apenas consultar o senhorio direto sobre a possibilidade de exercer seu direito de preferência. Logo, a possibilidade de transmitir a terra sempre existiu no regime enfitêutico, mas foi "impulsionada" a partir do momento em que a terra adquire destacável valor de troca - o que ocorre com a emergência do conceito de propriedade privada absoluta, o adensamento dos núcleos urbanos e a consequente escassez de terra urbanizada. Assim, o domínio bipartido da propriedade não seria um fator limitante ao parcelamento do solo pelos entes privados. Acredita-se que nos núcleos urbanos o parcelamento/venda da terra urbana seria mais estimulado pelo valor que ela adquiria em função de sua escassez le fora dos centros urbanos, pelo fim da possibilidade de adquirir terra por meio de concessão) do que pela desvinculação do domínio do Município ou da Coroa.

Observa-se, portanto, que a enfiteuse, por conferir direitos sobre a terra muito similares aos direitos do proprietário absoluto, dava ao enfiteuta liberdade para desmembrar, parcelar e remembrar a terra, tornando-o agente de participação significativa na estruturação morfológica da cidade. No entanto, o conceito de 
propriedade privada absoluta parece ter permeado a concepção de domínio da terra mesmo no sistema enfitêutico, de modo que questões como venda de terrenos (nesse caso, traspasse do domínio útil), iniciativa de parcelamento do solo e divisão da terra em lotes são incorporadas aos processos fundiários não à margem do sistema enfitêutico, mas dentro dele.

Logo, na cidade de Belém a noção de propriedade privada não levou ao rompimento formal com o sistema de aforamento de terras, mas o permeou de tal forma que o enfiteuta passa a ser encarado como proprietário absoluto das terras (apesar de estas ainda permanecerem sob domínio direto do Município) e é inserido no incipiente mercado de terras de maneira semelhante ao proprietário privado absoluto. Nesse contexto observa-se que, principalmente a partir de meados do século XIX, a Câmara usa sua prerrogativa de aforar terras de modo articulado com iniciativas de parcelamento e arruamento de certas áreas da cidade, maximizando sua atuação como fornecedora de terra. A expansão da cidade por meio do parcelamento e ocupação do entorno da Estrada de Bragança se insere em uma lógica fundiária de transferência de terras públicas para particulares, em um momento em que a propriedade privada da terra e sua comercialização se consolidavam e quando a possibilidade de adquirir terra urbana por valores irrisórios (via aforamento) é ameaçada. $O$ parcelamento do solo desenvolvido pela Câmara a partir da segunda metade do século XIX funciona como uma ponte entre um modelo fundiário tradicional, no qual a aquisição da terra ainda se dava por valores baixos, e o modelo moderno, caracterizado pela terra com valor de troca, passível de ser comercializada pelo adquirente a partir de um preço que inclui tanto o valor da disponibilidade da propriedade privada mediante a escassez, quanto a valorização da terra decorrente do desenvolvimento urbano e dos investimentos públicos.

Nesse sentido, o Plano de Expansão da Cidade, mais do que um instrumento de embelezamento e modernização espacial, atua como um instrumento público que viabiliza a partilha sistemática e a apropriação da terra nesse momento de transição da regulação e mentalidade fundiárias. A morfologia urbana moderna prevista no Plano tanto atendia à tipologia arquitetônica da época quanto impactava a distribuição e concentração de terras no local.

Nessa atuação da Câmara Municipal sobre o parcelamento do solo, os aforamentos exerceram papel fundamental na definição morfológica dos lotes, uma vez que os terrenos aforados no local deveriam seguir determinações como largura da testada, profundidade, terrenos confinantes e localização, estabelecidas pela Câmara. Esta definição precisa da forma e situação do terreno no ato do aforamento, oriunda do planejamento sistemático do parcelamento, permitiu que a conformação do terreno in loco se ativesse a esses direcionamentos na maioria dos casos. 
Foram, então, poucos os casos em que as ações de alinhamento e arrumação de terrenos desempenharam papel de definir ou redefinir a forma de lotes e vias nas áreas sujeitas ao parcelamento planejado. Acredita-se que o papel dessas ações nas áreas loteadas pelo Município foi menos contundente do que nos parcelamentos espontâneos, tendo sido principalmente um meio de garantir que a regularidade do traçado previamente definida no planejamento fosse implantada no local.

Dessa forma, o parcelamento do solo da Primeira Légua Patrimonial no século XIX foi marcado pela atuação pioneira do Município como agente loteador, exercendo sua tradicional função de fornecedor de terra e regulador da ocupação urbana dentro do novo molde de partilha fundiária que se consolida com o ideário moderno de propriedade - o loteamento. A Câmara Municipal, enquanto agente dotado de posição política e ideológica, exprime seus posicionamentos na definição da morfologia da cidade, conduzindo a apropriação do solo e induzindo ou acentuando relações socioespaciais que, por sua vez, condicionam novas formas de apropriação do espaço urbano, impactando a estruturação da cidade até os dias atuais.

Quando a situação da terra urbana era instável no país e a distinção entre patrimônio público e privado acentuava-se, a Câmara foi responsável pela formação de reservas fundiárias nas mãos de particulares, que puderam, a partir do adensamento do local, já no século XX, colher os frutos dos processos de valorização da terra. Nesse sentido, processos que hoje se percebem na cidade de Belém, como a ocupação de áreas alagáveis pela população de baixa renda, a ocupação informal de grandes áreas da cidade, a verticalização da ocupação no entorno da antiga Estrada de Bragança e outros, remontam às primeiras concessões de terra nessas áreas pela Câmara Municipal ainda no século XIX. Essas concessões e as transformações espaciais que se originam delas revelam o papel estruturador desempenhado pelo Município na ordenação tanto da estrutura fundiária quanto da morfologia da cidade, em virtude de sua situação privilegiada como detentor do domínio da Primeira Légua Patrimonial e agente estatal. 


\section{REFERÊNCIAS}

FONTES MANUSCRITAS

BELÉM. Relação de pessoas que arremataram terrenos à Câmara desta cidade: Luiza Valeria de Olvr ${ }^{\mathrm{a}}$, em 24 de outubro de 1759. In: Relação de pessoas que arremataram terrenos à Câmara de Belém. Arquivos da Companhia de Desenvolvimento e Administração da Área Metropolitana de Belém., 1752-1877a. livro 5, f. 6.

. Relação de pessoas que arremataram terrenos à Câmara desta cidade: Valentim Gomes, em 03 de dezembro de 1760. In: Relação de pessoas que arremataram terrenos à Câmara de Belém. Arquivos da Companhia de Desenvolvimento e Administração da Área Metropolitana de Belém, 1752-1877b. livro 5, f. 6.

Relação de pessoas que arremataram terrenos à Câmara desta cidade: Policarpo Antonio da $S^{a}$, em [?] de junho de 1770. In: Relação de pessoas que arremataram terrenos à Câmara de Belém. Arquivos da Companhia de Desenvolvimento e Administração da Área Metropolitana de Belém, 1752-1877c. livro 5, f. 8.

Termo de Aforamento registrado em nome de Roberto Hesketh Sobrinho no dia 19 de junho de 1869. In: Registro dos Termos Extraordinários de Aforamentos dos Terrenos do Patrimônio da Câmara Municipal de Belém. Arquivos da Companhia de Desenvolvimento e Administração da Área Metropolitana de Belém, 1850-1870a. livro 7, f. 62.

Termo de Aforamento registrado em nome de Manoel Roque Jorge Ribeiro no dia 20 de dezembro de 1869. In: Registro dos Termos Extraordinários de Aforamentos dos Terrenos do Patrimônio da Câmara Municipal de Belém. Arquivos da Companhia de Desenvolvimento e Administração da Área Metropolitana de Belém, 1850-1870b. livro 7, f. 82 .

Termo de Aforamento registrado em nome de Antonio Valente Cordeiro da Luz no dia 06 de outubro de 1869. In: Registro dos Termos de Aforamento dos Terrenos do Patrimônio da Câmara Municipal de Belém. Arquivos da Companhia de Desenvolvimento e Administração da Área Metropolitana de Belém, 1869a. livro 10, f. 13.

Termo de Aforamento registrado em nome de Antonio Francisco Pinheiro no dia 13 de outubro de 1869. In: Registro dos Termos de Aforamento dos Terrenos do Patrimônio da Câmara Municipal de Belém. Arquivos da Companhia de Desenvolvimento e Administração da Área Metropolitana de Belém, 1869b. livro 10, f. 59. 
BELÉM. Termo de Aforamento registrado em nome de Maria do Carmo no dia 07 de outubro de 1869. In:___ Registro dos Termos de Aforamento dos Terrenos do Patrimônio da Câmara Municipal de Belém. Arquivos da Companhia de Desenvolvimento e Administração da Área Metropolitana de Belém, 1869c. livro 10, f. 27.

Termo de Aforamento registrado em nome de Antonio Nicolau Monteiro Baena no dia 15 de outubro de 1869. In: Registro dos Termos de Aforamento dos Terrenos do Patrimônio da Câmara Municipal de Belém. Arquivos da Companhia de Desenvolvimento e Administração da Área Metropolitana de Belém, 1869d. livro 10, f. 77.

Registro dos Termos de Aforamento dos Terrenos do Patrimônio da Câmara Municipal de Belém. Arquivos da Companhia de Desenvolvimento e Administração da Área Metropolitana de Belém, 1869e. livro 10.

Registro dos Termos de Aforamento dos Terrenos do Patrimônio da Câmara Municipal de Belém. Arquivos da Companhia de Desenvolvimento e Administração da Área Metropolitana de Belém, 1869-1870. livro 11.

Registro dos Termos de Aforamento dos Terrenos do Patrimônio da Câmara Municipal de Belém. Arquivos da Companhia de Desenvolvimento e Administração da Área Metropolitana de Belém, 1870-1873a. livro 12.

Registro dos Termos de Aforamento dos Terrenos do Patrimônio da Câmara Municipal de Belém. Arquivos da Companhia de Desenvolvimento e Administração da Área Metropolitana de Belém, 1873-1883b. livro 18.

Registro dos Termos de Aforamento dos Terrenos do Patrimônio da Intendência Municipal de Belém. Arquivos da Companhia de Desenvolvimento e Administração da Área Metropolitana de Belém, 1895-1912. livro 23.

Registro dos Termos de Aforamento dos Terrenos do Patrimônio da Intendência Municipal de Belém. Arquivos da Companhia de Desenvolvimento e Administração da Área Metropolitana de Belém, 1913-1931. livro 25.

Termo de Arrumação e Alinhamento registrado em nome de Antonio Francisco Pinheiro no dia 11 de novembro de 1885. In: Registro dos termos de arrumação e alinhamento dos terrenos foreiros à Câmara Municipal de Belém. Arquivos da Companhia de Desenvolvimento e Administração da Área Metropolitana de Belém, 1884-1885. livro 8, f. 130vº.

Termo de Arrumação e Alinhamento registrado em nome de Joanna de Sequeira Rodrigues Baena no dia 10 de outubro de 1900. In:___ Registro dos termos de arrumação e alinhamento dos terrenos foreiros à Intedência Municipal de Belém. Arquivos da Companhia de Desenvolvimento e Administração da Área Metropolitana de Belém, 1900-1902a. livro 11, f. 53. 
BELÉM. Termo de Arrumação e Alinhamento registrado em nome de Antonio A. Nunes e outros no dia 29 de novembro de 1901. In: Registro dos termos de arrumação e alinhamento dos terrenos foreiros à Intedência Municipal de Belém. Arquivos da Companhia de Desenvolvimento e Administração da Área Metropolitana de Belém, 1900-1902b. livro 11, f. 169.

Termo de Arrumação e Alinhamento registrado em nome de Antonio Joaquim Fernandes em 07 de fevereiro de 1905. In: Registro dos termos de arrumação e alinhamento dos terrenos foreiros à Intedência Municipal de Belém. Arquivos da Companhia de Desenvolvimento e Administração da Área Metropolitana de Belém, 1902-1905. livro 12, f. 66.

FONTES IMPRESSAS

ALMEIDA, Cândido Mendes de (Org.). Ordenações filipinas. Rio de Janeiro: Typ. do Instituto Philomathico, 1870. livro 1.

BERREDO, Bernardo Pereira de. Annaes historicos do estado do Maranhaõ: em que se dá noticia de seu descobrimento, e tudo o mais que nelle tem succedido desde o anno em que foy descuberto até o de 1718. Lisboa: Officina de Francisco Luiz Ameno, 1749. 710 p.

JORNAL DO PARÁ (Ed.). Câmara Municipal do Pará: Requerimentos. Jornal do Pará: órgão official. Belém, 27 mar. 1873. Interior, p. 1.

O LIBERAL DO PARÁ (Ed.). Câmara Municipal: Expediente. O Liberal do Pará. Belém, 18 fev. 1871. Interior, p. 1-2.

A Camara Municipal da capital. O Liberal do Pará. Belém, 7 abr. 1870. Communicado, p. 2.

As accusações da constituição. O Liberal do Pará. Belém, 7 mar. 1874. Liberal do Pará, p. 1 .

COMPANHIA DE DESENVOLVIMENTO E ADMINISTRAÇÃO DA ÁREA METROPOLITANA DE BELÉM. Projeto de saneamento para recuperação das baixadas de Belém: Bacia do Una. Belém, 1998. (Projeto de desapropriação/relocação, v. 7).

FIGUEIREDO, Cândido. Novo dicionário da língua portuguesa. Lisboa: Instituto Coimbra, 1913.

FREITAS, Augusto Teixeira de. Consolidação das Leis Civis. ed. fac-sim. Brasília, DF: Senado Federal, 2003. v. 1. 
MUNIZ, João de Palma. Patrimônios dos Conselhos Municipaes do Estado do Pará. Lisboa: Aillaud \& Cia, 1904.

PARÁ. Relatorio do Exm ${ }^{\circ}$ Senr. Angelo Thomaz do Amaral Presidente da Provincia do GramPará ao Exm ${ }^{\circ}$ Vice-presidente Olyntho José Meira: por ocasião de passar-lhe a administração da mesma. Belém: Santos \& Irmãos, 1861.

SÃO PAULO. Revista do arquivo municipal. 61-63. ed. São Paulo: Prefeitura Municipal; Secretaria de Educação e Cultura; Departamento de Cultura, 1939. v. 6.

SILVA, Antonio de Morais. Diccionario da lingua portugueza. Rio de Janeiro; Lisboa: Empreza Litteraria Flumninense, 1890. v. 1.

LIVROS, ARTIGOS E TESES

ABREU, Maurício de Almeida. A apropriação do território no Brasil Colonial. In: CASTRO, I. E. de; GOMES, P. C. C.; CORRÊA, R. L. (Orgs.). Explorações geográficas: percursos no fim do século. Rio de Janeiro: Bertrand Brasil, 1997.

ALBUQUERQUE, Antônio Paul. Rocinhas e Puxadas. Revista do tecnológico, Belém, v. 2, n. 1, p 1-63. 1989.

BENEVOLO, Leonardo. História da arquitetura moderna. São Paulo: Perspectiva, 2009.

BUENO, Beatriz Piccolotto Siqueira. Tecido urbano e mercado imobiliário em São Paulo: metodologia de estudo com base na Décima Urbana de 1809. Anais do Museu Paulista, São Paulo, v. 13, n. 1, p. 59-97, 2005.

CARDOSO, Patrícia de Menezes. Democratização do acesso à propriedade pública no Brasil: função social e regularização fundiária. São Paulo, 2010.

CORRÊA, Sirotheau. O município de Belém e a Segunda Légua Patrimonial. Revista do Tribunal de Justiça, Belém, n. 17, [19--].

CONZEN, Michael P. The study of urban form in the United States. Urban Morphology, Birmingham, v. 5, n. 1, p. 3-14, 2001.

CRUZ, Ernesto. História de Belém. Belém: Universidade Federal do Pará, 1973. 2 v. 
CRUZ, Ernesto. Procissão dos séculos: vultos e episódios da história do Pará, 1999.

DI PIETRO, Maria Sylvia Zanella. Direito Administrativo. 21. ed. São Paulo: Atlas, 2008.

DUARTE, Cristovão Fernandes. Gênese da cidade moderna brasileira: o caso de Belém. In: ENCONTRO NACIONAL DA ANPUR, 7., 1997. Recife. Anais... Recife: Anpur, 1997a. v. 1, p. 425-438.

Belém do Pará, na virada do século XIX: modernidade no plano urbanístico de expansão da cidade. 1997. 101 f. Dissertação (Mestrado em Arquitetura e Urbanismo) Universidade Federal do Rio de Janeiro, Rio de Janeiro, 1997b.

ERSLAND, Geir Atle. Plot Longevity and Urban Land Tenure: a Norwegian Case Study. Urban Morphology, Birmingham, v. 14, n. 1, p. 21-29. 2010.

FONSECA, Cláudia Damasceno. Arraiais e vilas d'el rei: espaço e poder nas Minas setecentistas. Belo Horizonte: EdUFMG, 2011.

Urbs e civitas: a formação dos espaços urbanos e territórios urbanos nas Minas setecentistas. Anais do Museu Paulista, São Paulo, v. 20, n. 1, p. 77-108, 2012.

FRANCO, Luiz Fernando P. N. Por uma história da forma urbana: análise de uma amostra de tecido do centro histórico de Belém. In: SEMINÁRIO SOBRE DESENHO URBANO, 2., 1986, Brasília, DF. Anais... Brasília, DF: CNPq, 1986. p. 330-339.

FRIDMAN, Fania. Donos do Rio em nome do rei: uma história fundiária da cidade do Rio de Janeiro. Rio de Janeiro: Jorge Zahar, 1999.

GLEZER, Raquel. Chão de terra e outros ensaios sobre São Paulo. São Paulo: Alameda, 2007a.

Persistências do Antigo Regime na legislação sobre a propriedade territorial urbana no Brasil: o caso da cidade de São Paulo (1850-1916). Revista Complutense de Historia de América, Madri, v. 33, p. 197-215, 2007b.

GODOY, Marcos Felipe. A apropriação e os usos dos chãos urbanos em São Paulo colonial (séculos XVI-XVIII). In: SIMPÓSIO NACIONAL DE HISTÓRIA, 28., 2015, Florianópolis. Anais.... Florianópolis: Anpuh, 2015. p. 1-18.

GUIMARÃES, Luiz Antonio Valente. As casas $\mathcal{E}$ as coisas: um estudo sobre vida material e domesticidade nas moradias de Belém - 1800-1850. 2006. 195 f. Dissertação (Mestrado em História Social da Amazônia) - Universidade Federal do Pará, Belém, 2006. 
LAPA, José Roberto do Amaral. A cidade: os cantos e os antros (Campinas 1850-1900). São Paulo: Edusp, 1996.

LEONELLI, Gisela Cunha Viana. A construção da lei federal de parcelamento do solo urbano 6.766: debates e propostas do início do sec. XX a 1979. 2010. 294 f. Tese (Doutorado em Arquitetura e Urbanismo) - Universidade de São Paulo, São Carlos, 2010.

LIMA, Ruy Cirne. Pequena história territorial do Brasil: sesmarias e terras devolutas. Porto Alegre: Sulina, 1990.

LOBATO, Célio Cláudio de Queiroz et al. Um olbar sobre os aspectos da infra-estrutura e do planejamento urbano em Belém do Pará. Belém: Cesupa, 2005.

MARX, Murillo. Cidade no Brasil: terra de quem? São Paulo: Nobel; Edusp, 1991.

Cidade no Brasil: em que termos? São Paulo: Nobel, 1999.

MEIRA FILHO, Augusto. Evolução histórica de Belém do Grão Pará. Belém: M2p Arquitetura e Engenharia, 1976.

MIRANDA, Marcia Eckert. Continente de São Pedro: a administração pública no período colonial. Porto Alegre: Assembleia Legislativa do Estado do Rio Grande do Sul; Ministério Público do Rio Grande do Sul; Corag, 2000.

MONTEIRO, Claudio. O domínio da cidade: a propriedade à prova no direito do urbanismo. 2010. 590 f. Tese (Doutorado em Direito Administrativo) - Universidade de Lisboa, Lisboa, 2010.

MOREIRA, Eidorfe. Belém e sua expressão geográfica. Belém: Imprensa Universitária, 1966.

MOTA, Maria Sarita. Sesmarias e propriedade titulada da terra: o individualismo agrário na América Portuguesa. Saculum, João Pessoa, v. 26, p. 29-45, 2012.

MOUDON, Anne Vernez. Urban morphology as an emerging interdisciplinary field. Urban Morphology, Birmingham, v. 1, n. 1, p. 3-10, 1997.

MOURÃO, Leila. O conflito fundiário urbano em Belém (1960-1980): a luta pela terra de morar ou de especular. Belém: Universidade Federal do Pará, 1987. 148 f. 
NASCIMENTO, Rebeca Maria Aguiar do. Processo de privatização da terra urbana e suas implicações na cidade da Parahyba. In: SIMPÓSIO NACIONAL DE GEOGRAFIA URBANA, 13. 2013, Rio de Janeiro. Anais... Rio de Janeiro: UERJ, 2013. p. 1-20.

NASCIMENTO, Rebeca Maria Aguiar do; MAIA, Doralice Sátyro. Os impactos iniciais da Lei de Terras de 1850 na estrutura fundiária da cidade da Parahyba. Geotextos, Salvador, v. 7, n. 2, p. 45-68, 2011.

OLIVEIRA, Natalia Altieri Santos de; FISCHER, Luly Rodrigues da Cunha. Registros paroquiais da freguesia de Benfica em Belém: análise da origem fundiária. Revista Brasileira de História do Direito, Florianópolis, v. 3, n. 2, p. 42-60, 2017.

PENTEADO, Antônio Rocha. Belém: estudo de geografia urbana. Belém: UFPA, 1988.

RIBEIRO, Fernando Victor Aguiar. Os direitos de propriedade da terra urbana na América portuguesa: o caso do município de São Paulo colonial. História, São Paulo, v. 36, n. 1, p. 1-25, 2017.

SARGES, Maria de Nazaré. Belém: riquezas produzindo a Belle-Époque (1870-1912). Belém: Paka-Tatu, 2000.

SEGAWA, Hugo. Arquiteturas no Brasil: 1900-1990. São Paulo: Edusp, 2010.

SIMONI, Lucia Noemia. A planta da cidade de São Paulo de 1897: uma cartografia da cidade existente ou da cidade futura? In: SIMPÓSIO LUSO-BRASILEIRO DE CARTOGRAFIA HISTÓRICA, 3., 2009, Ouro Preto. Anais... Belo Horizonte: Centro de Referência em Cartografia Histórica, 2009. p. 1-18.

SMITH, Roberto. Propriedade da Terra \& Transição: estudo da formação da propriedade privada da terra e transição para o capitalismo no Brasil. São Paulo: Brasiliense, 1990.

\section{LEGISLAÇÕES}

BELÉM. Lei Ordinária n ${ }^{\circ}$ 6.795, de 24 de abril de 1970. Dispõe sobre a Constituição da CODEM e dá outras providências. Diário Oficial do Município, Belém, 24 abr. 1970. Disponível em: <https://bit.ly/2CnAM9v>. Acesso em: 17 out. 2018.

. Secretaria Municipal de Coordenação Geral do Planejamento e Gestão (Orgs.). Coleção Mapas de Belém: formas de apropriação e uso do território. Belém: Segep; Funpapa, 2000. 
BRASIL. Lei de $1^{\circ}$ de outubro de 1828. Dá nova fórma ás Camaras Municipaes, marca suas attribuições, e o processo para a sua eleição, e dos Juizes de Paz. Coleção Leis do Império do Brasil, Rio de Janeiro, 18 out. 1828. v. 1, p. 74. Disponível em: <https://bit.ly/2CnOFoh>. Acesso em: 17 out. 2018.

. Lei $\mathrm{n}^{\circ}$ 581, de 4 de setembro de 1850 . Estabelece medidas para a repressão do trafico de africanos neste Imperio. Coleção Leis do Império do Brasil, Rio de Janeiro, 4 set. 1850. v. 1, p. 267. Disponível em: <https://bit.ly/2D4qOLs>. Acesso em: 25 out. 2018.

. Lei $\mathrm{n}^{\circ}$ 601, de 18 de setembro de 1850. Dispõe sobre as terras devolutas do Império. Coleção Leis do Império do Brasil, Rio de Janeiro, 18 set. 1850. v. 1, p. 301. Disponível em: <https://bit.ly/2q0aSBv>. Acesso em: 17 out. 2018.

Decreto $\mathrm{n}^{\circ} 1.318$, de 30 de janeiro de 1854. Manda executar a Lei $\mathrm{n}^{\circ} 601$, de 18 de setembro de 1850. Coleção Leis do Império do Brasil, Rio de Janeiro, 30 jan. 1854. v. 1, p. 10. Disponível em: <https://bit.ly/2pZ0kT1>. Acesso em: 17 out. 2018.

Decreto $\mathrm{n}^{\circ}$ 58, de 10 de dezembro de 1937. Dispõe sobre o loteamento e a venda de terrenos para pagamento em prestações. Coleção de Leis do Brasil, Rio de Janeiro, 10 dez. 1937. v. 3, p. 375. Disponível em: <https://bit.ly/2ELS0QU>. Acesso em: 25 out. 2018.

Decreto $\mathrm{n}^{\mathrm{o}} 3.079$, de 15 de setembro de 1938. Regulamenta o Decreto-Lei n 58, de 10 de dezembro de 1937 , que dispõe sobre o loteamento e a venda de terrenos para pagamento em prestações. Diário Oficial da União, Rio de Janeiro, 15 set. 1937. Disponível em: <https:// bit.ly/2BYbEWN>. Acesso em: 25 out. 2018.

Decreto $\mathrm{n}^{\circ}$ 6.766, de 19 de dezembro de 1979. Dispõe sobre o parcelamento do solo urbano e dá outras providências. Diário Oficial da União, Brasília, 19 dez. 1979. Disponível em: <https://bit.ly/2NZEn0N>. Acesso em: 25 out. 2018.

Código Civil: quadro comparativo 1916/2002. Brasília, DF: Senado Federal, Subsecretaria de Edições Técnicas, 2003. Disponível em: <https://bit.ly/2rZAcbx>. Acesso em: 17 out. 2018.

SITES E MATERIAIS DIGITAIS

CADASTRO municipal. Belém: Câmara Municipal, 2000. 1 CD-ROM.

CONCELHO. In: DICIONÁRIO Priberam da língua portuguesa. Lisboa: Priberam Informática, 2018. Disponível em: <https://bit.ly/2R2IYQX>. Acesso em: 17 out. 2018. 
Artigo apresentado em 23/04/2018. Aprovado em 11/09/2018.

\section{(cc) BY}

All the contents of this journal, except where otherwise noted, is licensed under a Creative Commons Attribution License 